\title{
BACK TO THE FUTURE: THE MANAGED CARE REVOLUTION
}

\author{
GAIL B. AgRAWAL* AND HOWARD R. VEIT**
}

\section{INTRODUCTION}

Revolutions that result in sudden and radical change to a society's essential attributes are rare occurrences. Rather, from biology to social policy, the present is the result of an evolutionary progression of interrelated phenomena. The forces that prompt a period of rapid evolution are often not apparent, except in hindsight. The evolutionary process, once begun, is difficult to orchestrate, and the results hard to predict. The evolution of the managed care industry is a case in point. Initiatives by the private sector and government to make medical care accessible to a larger percentage of the population exacerbated, rather than ameliorated, the costs of health care services. The market-based reforms that followed were intended to provide consumers with information and financial incentives to make wise economical choices, but instead gave rise to a clamor of consumer complaints, while posting only temporary gains in controlling health care costs. The nation is once again faced with calls for reform of its patchwork system of health care delivery and financing.

This article provides an overview of the interrelated events that led to the present-day managed care system. We begin with the stimuli for change to the longstanding medical model status quo. A paradigmatic shift from a physiciandominated professional model to a market-based system characterized the revolutionary period that followed. Before that shift could occur, however, Congress had to abandon its regulatory zeal to create a political climate in which policy-makers perceived market-based reform as a viable alternative to both regulatory fiat and professional control. Equally important to legislative willingness was the elimination of systemic impediments to market reforms, principally the organized resistance of the professionals who controlled the system. These events opened the way for suggestions about the direction that market-driven evolution should follow and the translation of scholarly insight

Copyright (C) 2002 by Gail B. Agrawal and Howard R. Veit

This article is also available at http://www.law.duke.edu/journals/65LCPAgrawal.

* Professor of Law, University of North Carolina at Chapel Hill.

** National Practice Leader for the Health Care Industry Consulting Practice at Towers Perrin (Retired) and former Director of the Federal Office of Health Maintenance Organizations, Department of Health and Human Services.

The authors thank John Mayoras for research assistance and the Symposium participants for their insights and suggestions. The authors also wish to thank Professor Peter Jacobson. 
into political reality. In this article, we revisit these events, describe the system that evolved, and conclude with some suggestions for future directions.

\section{II}

\section{The PAST AS PRELUde}

The story of the pre-managed care era is one of miscues and well-intentioned missteps. Although the stirrings of the health care revolution became readily apparent shortly after the enactment of the Medicare and Medicaid programs, both the events that gave rise to the need for change and the form that change took had much earlier origins. The years that preceded the managed care era were remarkable for the juxtaposition of the relative stability and lack of diversity among the organizational arrangements for the delivery and financing of health care services, and the rapid changes in society and medical science. As third-party financing grew and physicians expanded their sphere of influence to include payment mechanisms as well as health care delivery, attempts to expand access to health care services without fundamentally changing highly prized practice patterns led to unsustainable levels of health care spending.

The health care delivery system had long been static. Most physicians were self-employed, predominantly in solo practice, and the ratio between capital and labor in the typical practice was low. ${ }^{1}$ Vertical integration of individual and institutional providers was rare. The result was a non-system of independent small business bereft of any means to coordinate the delivery of medical services to ensure their continuity, quality, or cost-effectiveness.

The efforts to finance health care services exhibited only slightly more variation. In the early years of the twentieth century, medical services were a market good. As with all market goods, an individual's access to health care services was based primarily on her ability to buy them. The resulting harshness to those unable to pay was mediated by the philanthropic leanings of the wealthy and the benevolence of physicians, but those were by no means certain. Predictably, means to increase access to affordable medical services evolved. Between 1900 and the early 1930s, some single institutions aligned with closed groups of physicians to offer their health care services to employers for a fixed periodic prepayment. ${ }^{2}$ These plans were usually ad hoc arrangements, with the institutions and the physicians continuing their separate practices while coordinating some services and offering them on a prepaid, fixed price basis. ${ }^{3}$ In addition to these partial alignments, the period before World War I saw the first establishment of physician group practices that provided services solely on a prepaid basis to closed panels of patients. ${ }^{4}$ Before 1933, these provider-initiated

1. See generally Victor R. Fuchs, Can the Traditional Practice of Medicine Survive?, 125 ARCHIVES INTERNAL MED. 154 (1970) [hereinafter Fuchs, Traditional Practice].

2. Charles D. Weller, "Free Choice" as a Restraint of Trade in American Health Care Delivery and Insurance, 69 IOWA L. REV. 1351, 1352, 1355-64 (1984).

3. Id. at 1360-64.

4. Barbara A. Shickich, Legal Consequences of the Health Maintenance Organization, in 
arrangements were the predominant means of group financing of health care services, although they covered only a small percentage of the population.'

The Depression years highlighted the need for a systematic means of financing health care services for a greater percentage of the population than the isolated provider-initiated efforts at prepaid care had achieved. With health care services out of reach for many, there were calls for a national health insurance system, calls that were answered by private initiatives to provide financing for medical services. ${ }^{6}$ The form and business practices the early third-party payers adopted were heavily influenced by organized medicine. The American Medical Association insisted that an all-qualified-caregivers approach was the only ethical model for group financing of health care services; it decried the unethical nature of prepaid group practice that depended upon limited, closed physician panels. ${ }^{7}$ Physicians in prepaid provider-sponsored plans found themselves ostracized by their professional peers. ${ }^{8}$ Over time, the market share of prepaid health care eroded, although prepaid health care continued in some limited geographic areas.'

In 1933, hospitals and physicians began to organize the Blue Cross plans for coverage of hospital costs and Blue Shield plans for physician care. These early financing models, devised by caregivers, were created in the image of the existing physician-dominated health care delivery system. They were organized as non-profit entities that embraced a so-called community choice model, discouraging competition by permitting all qualified physicians and hospitals in the community to participate and reflecting professional disapproval of others profiting from the practice of medicine. ${ }^{10}$ Premiums were based on a community rating, a tacit acceptance of the principle that the costs of illness should be shared among the healthy and the unhealthy. ${ }^{11}$ Physicians were paid directly for their services on the basis of their charges, limited by the amorphous and physician-determined level of the "usual, customary, and reasonable" fee in the community. Hospitals were paid on the basis of their incurred costs. ${ }^{12}$

Commercial insurers soon entered the health care coverage market offering indemnity coverage at premiums based on experience rating. They also

HeAlthCARE FACiLities Law 1051, 1053-60 (Anne M. Dellinger ed., 1991).

5. Weller, supra note 2, at 1363 . The vast majority of the population had no health care coverage and paid from their personal resources or received charity care.

6. PAUl StARR, THE SOCIAL TRANSFORMATION OF AMERICAN MEDicine 280-86 (1982).

7. The American Medical Association stated that prepaid practice involved "solicitation of patients, destructive competition among professional groups, inferior medical service, loss of personal relationship of patient and physician, and demoralization of the profession." See BUREAU OF ECONOMICS STAFF REPORT ON THE HEALTH MAINTENANCE ORGANIZATION AND ITS EFFECTS ON COMPETITION 7 n.1 (July 1977) (quoting J. AM. MED. Ass'N, Dec. 3, 1932, at 1951).

8. See, e.g., Am. Med. Ass'n v. United States, 317 U.S. 519 (1943).

9. See generally Thomas Mayer \& Gloria Gilbert Mayer, HMOs: Origins and Development, 312 NEW ENG. J. MED. 590 (1985).

10. BARry R. Furrow ET AL., HeAlth LAW § 9-1, 462-63 (2d ed. 2000); see also Weller, supra note 2 , at $1364-65$.

11. STARR, supra note 6 , at 309.

12. Weller, supra note 2, at 1365. 
adopted an all-provider participation model and made no attempt to influence the services provided or the amounts charged by caregivers to their insureds. ${ }^{13}$ If the insurers had tried to exert such influence, organized medicine would likely have blocked their efforts, in much the same way that they had stymied early prepaid practices.

The World War II years saw a great expansion in employer-based health care coverage, as a result of wartime wage-caps and the substitution of benefit enhancements for salary increases. Congress encouraged employer-based health care coverage by amending the Internal Revenue Code of 1954 to exclude employer-provided coverage from employees' taxable income while permitting employers to deduct the cost of employee coverage as a business expense..$^{14}$ Conventional insurers, including commercial carriers and the servicebased Blue Cross and Blue Shield plans, became the coverage of choice for employment-based communities of insureds. ${ }^{15}$

As the level of third-party coverage increased, public acceptance of medical care as a market good eroded. ${ }^{16}$ In 1965, the federal government created the Medicare program to provide public insurance to individuals sixty-five and over and to those with certain disabilities, and joined with the states under the auspices of the Medicaid program to extend health care coverage to those considered categorically or medically needy. ${ }^{17}$ Following the lead of the Blue Cross/Blue Shield and commercial insurance plans, as well as the urgings of professional associations, these government programs initially adopted fee-forservice reimbursement for physician services and cost-based reimbursement for hospital services. ${ }^{18}$

Flaws in the pre-1970s delivery system and financing mechanisms were a powerful impetus for the health care revolution. Because of their professional expertise and the almost mythical regard in which their patients held them, physicians controlled both the supply of and the demand for health care services. Patient trust coupled with the lack of readily available, comprehensible information inhibited competition on the basis of medical quality. Moreover, physicians enjoyed de facto control over the types of insurance plans that would be

13. See STARR, supra note 6, at 204-06 (noting that group health insurance "freed the medical profession" from corporate control).

14. See I.R.C. § 106 (1986).

15. DAVID B. SMith, The White LABYRINTH: Understanding THE ORganization OF HEALTH CARE 39-41 (1975).

16. See Walter McClure, The Medical Care System under National Health Insurance: Four Models, 1 J. HeAlth POL. POL'Y \& L. 22, 25 (1976) [hereinafter McClure, Medical Care System] (noting that the availability of third-party payment for medical services turned health care from a market good to merit good).

17. For a discussion of the effect of Medicare and Medicaid legislation on the medical profession, see Eliot Freidson, The Medical Profession in Transition, in APPLICATIONS OF SOCIAL SCIENCE TO Clinical Medicine and Health Policy 63 (Linda H. Aiken \& David Mechanic eds., 1986).

18. Later, the federal government would respond to the cost-increasing effects of cost- and charges-based methods of reimbursement and adopt a prospective payment system for hospital reimbursement and a resource-based relative value scale to set physician payment. 
available to consumers. ${ }^{19}$ The practical effect of the all-qualified-caregivers' model of health care coverage was an almost total elimination of competition among physicians on the basis of price. ${ }^{20}$ In an earlier era, when patients were responsible for a significant portion of their medical bills, the physician's medical largess was tempered by the patient's financial limitations. The availability of third-party payers, however, decreased the price sensitivity of physician and patient. Consumer-insensitivity to cost predictably led to higher charges, which made third-party coverage more attractive. Although the employer group seemed a sensible method for creating a community of insureds, and employerpaid coverage an expedient way to provide financing for health care services, these practices exacerbated insured employees' insensitivity to the costs of both medical services and insurance coverage. Federal tax policy contributed to the difficulties as insured employees sought ever-increasing levels of employer-provided coverage to take advantage of the ability to pay for health care services with pre-tax dollars. ${ }^{21}$

While conventional insurers enjoyed early marketplace successes, they adopted business practices that produced unanticipated harmful effects elsewhere in the system. Cost-based reimbursement for hospital services encouraged hospitals to incur greater costs. Because health care insurance provided generous coverage for hospital services and frequently did not pay for outpatient services, patients and physicians preferred inpatient to less costly outpatient care. Combined with the availability of funding under the Hill-Burton Act, hospitals, the most costly option for care delivery, became the locus of care in large and small communities. Health care spending increased, and with it came a necessary increase in health care premiums and greater need for health care coverage.

Aided by the ready infusion of money from third-party payers, the late 1960s began a period of medical technological revolution with the development of new diagnostic and therapeutic tools. Despite the nation's already significant investment in health care, however, flaws began to appear in the "best health care system in the world." With new medical interventions came the opportunity for choice among treatment modalities. ${ }^{22}$ The speed with which these new interventions developed made clinical effectiveness difficult to verify. Physician autonomy over clinical practice resulted in wide variations in medical practice not associated with improved outcomes or differential medical need. The deliv-

19. See Hearing on H.R. 5740 Before the House Subcomm. on Health, Ways \& Means Comm. [hereinafter Hearing on H.R. 5740], 96th Cong. 126 (1980) (statement of Clark C. Havighurst).

20. See Alain C. Enthoven, Health Plan 23 (1980); see also Am. Med. Ass'n v. United States, 130 F.2d 233 (D.C. Cir. 1942), aff'd 317 U.S. 519 (1943) (AMA and affiliated doctors conspired to prevent an early prepaid plan from obtaining and retaining physician staff).

21. Clark Havighurst, Contract Failure in the Market for Health Services, 29 WAKE FOREST L. REV. 47, 57-59 (1994).

22. Alain C. Enthoven, Theory and Practice of Managed Competition in Health Care Finance, 9 PROFESSOR DR. F. DE VRIES LECTURES IN ECONOMICS: THEORY, INSTITUTIONS, POLICY 23 (1988) [hereinafter Enthoven, Theory and Practice] ("[M]edicine increasingly involves choices among costly and powerful technologies."). 
ery system was increasingly characterized by large numbers of seemingly inappropriate medical interventions and unnecessary, or inappropriately long, hospital stays. ${ }^{23}$ The predominant solo practice model did not lend itself either to outcomes measurements to assess the quality of care that resulted from clinical variability or to implementation of improvements if quality problems were identified.

Population growth, particularly among the aged and the poor, and steady increases in urbanization and industrialization soon led to an inequitable geographic distribution of health care manpower and resources, with more affluent citizens in suburban and urban areas having greater access to medical services than other citizens. ${ }^{24}$ The financial and psychic rewards associated with increased specialization resulted in a physician maldistribution, with more specialists and fewer generalists than were optimal to meet community medical needs. ${ }^{25}$ The result was a costly, two-tiered, fragmented delivery system. ${ }^{26}$

III

\section{THE REVOLUTION BEGINS}

In 1972, then-Secretary of Health, Education, and Welfare Elliot L. Richardson declared a "health care crisis" caused by escalating health care spending, unavailability of or inadequate access to health care services in inner cities and rural areas, fragmented services to the medically indigent, and insufficient use of preventive measures to reduce the incidence and severity of illness. ${ }^{27}$ President Nixon called for "[a]n all-directions reform of our health care system-so that every citizen will be able to get quality health care at reasonable cost regardless of income and regardless of area of residency." ${ }^{28} \mathrm{He}$ identified health care reform as "an item of highest priority on my unfinished agenda for America." 29 Thus, in the years before the managed care era of the 1980s and 1990s, the stated goal for an American health care revolution was high-quality medical care available and accessible to all who needed it without regard to their ability to pay. ${ }^{30}$

23. Paul M. Ellwood, Jr. et al., Assuring the Quality of Health Care 27-34, 53 (InterStudy 1973); see also Alain C. Enthoven et al., Consumer Choice and the Managed Care Backlash, 27 AM. J. L. \& MED. 1 (2001) [hereinafter Enthoven et al., Backlash].

24. Anne R. Somers, Some Basic Determinants of Medical Care and Health Policy, in Politics AND LAW IN HEAlth CARE POLICY 307 (John B. McKinlay ed., 1973).

25. Paul M. Ellwood, Jr., Concept, Organization and Strategies of HMOs, 3 J. NURSING AdMIN. 29, 33 (1973) [hereinafter Ellwood, Concept].

26. Herman M. Somers \& Anne R. Somers, Major Issues in National Health Insurance, 50 MilbanK Memorial Fund Q. 177, 201 (1972) [hereinafter Somers \& Somers, Major Issues].

27. Health Maintenance Organization Act: Hearings on H.R. 5615 and H.R. 11728 (and all identical bills) before the Subcomm. on Pub. Health \& Env. of the House Comm. on Interstate \& Foreign Commerce, 92nd Cong., 2d Sess. 56 (1972) [hereinafter Hearings on H.R. 5615].

28. President Richard M. Nixon, Message from the President of the United States Relative to the Health Care Program, H.R. Doc. No. 92-261 (Mar. 2, 1972).

29. Id.

30. See, e.g., Ellwood, Concept, supra note 25, at 30 (stating that the goal is quality health care for all); Paul M. Ellwood, Jr., How Can Change in Methods and Interrelationships within the Health Care 
The widespread agreement on the need for change quickly dissipated, however, when the subject turned to the means to facilitate health care reform. A few health care scholars urged market-based reform. ${ }^{31}$ Most lawmakers resorted to familiar regulatory approaches. Organized medicine attempted to retain its customary control over health care delivery and financing by resisting increased government intervention in much the same way as it had earlier resisted attempts at prepaid medical practice. ${ }^{32}$ For several years after the need for change became obvious, the debate was limited to the familiar dichotomous choice: government control or physician control.

The 1970s saw the proposal of several comprehensive regulatory models to achieve universal health care coverage. ${ }^{33}$ Senator Edward Kennedy introduced his "Health Security" plan in 1970, and when it did not garner the necessary support in Congress, followed it with "Health Care for All Americans" in $1979 .{ }^{34}$ Although the details of the two proposals differed, ${ }^{35}$ both plans called for the establishment of a federal health board that would establish and oversee a national health policy. Health care spending would be limited by a predetermined national budget. Funding for health care coverage would be based on federal taxes and general revenues. Coverage would be compulsory and universal.

Presidents Nixon and Carter proposed strategies that combined a government role with government mandated employer coverage for employed Ameri-

Industry be Brought About?, 50 ARCH. OF PHYSICAL MED. \& REHAB. 549, 551 (1969) [hereinafter Ellwood, Change in Methods] (same); McClure, Medical Care System, supra note 16, at 23 (stating that use of health care services should not be determined by income or personal circumstances but rather by medical need); Somers \& Somers, Major Issues, supra note 26, at 180 (advocating universal health insurance to increase access to health care).

31. See infra text accompanying notes 54-63, 70-87, 91-93 (discussing reforms suggested by Paul Ellwood, Alain Enthoven, Victor Fuchs, and Clark Havighurst).

32. See Mark A. Peterson, From Trust to Political Power: Interest Groups, Public Choice, and Health Care, 26 J. HeAlTH POL. POL'Y \& LAW 1145, 1151-53 (2001).

33. Comprehensive regulatory schemes also had their scholarly proponents. Anne and Herman Somers proposed a comprehensive system of universal health insurance that would have entailed substantial government intervention in health care financing. Underwriting and administrative processes of private insurance carriers would be regulated, and carriers would be subject to government approval. The Somers model envisioned that the federal government would set a national health care budget, establish a capitation premium for each approved carrier based on its enrolled population, and provide financing to individuals to obtain coverage. It would also ensure that consumers received comprehensive information about coverage options presented in a uniform manner. The federal government would oversee enrollment and create appeals processes for consumers and physicians who disagreed with decisions made by carriers. The health care delivery system would remain separate from the health care financing system and, in contrast to that system, free of direct government control. See, e.g., Somers \& Somers, Major Issues, supra note 26 (recommending a compulsory universal health insurance system with comprehensive coverage and funded by the federal government). Anne Somers continues to support a system that depends on the federal government to provide leadership for and oversight of a national health insurance program based on federal funding for a basic health insurance benefit design administered locally by a limited number of government-approved carriers. See generally Anne R. Somers, Toward a Comprehensive Reform of U.S. Health Care, 7 HEALTH CARE L. \& ETHICS 29 (1992).

34. See Enthoven, Health Plan, supra note 20, at 158-67 (discussing the Kennedy plans).

35. The latter plan provided an enhanced role for the states. 
cans. $^{36}$ Under these proposals, everyone who was not covered by employer plans would be entitled to publicly funded health insurance. Each of the presidential proposals envisioned a federally established standardized comprehensive coverage package with mandated employer and employee financial contributions. ${ }^{37}$ Unlike the Kennedy plans, both the Nixon plan, based on the work of Scott Fleming, and the later Carter plan, drawing from the work of Alain Enthoven, incorporated competitive elements within a large centralized system. $^{38}$ A more moderate approach was reflected in the Long-Ribicoff bill that would expand comprehensive coverage for low-income families and provide only catastrophic coverage for everyone else. Little progress was made toward reconciling the different strategies to develop a national insurance system. In the end, members of Congress showed little enthusiasm for comprehensive federal programs. None garnered the necessary support. ${ }^{39}$

The use of a more limited command-and-control style regulatory model was short-lived. In 1971, President Richard Nixon announced an Economic Stabilization Program that would freeze wages and prices for a ninety-day period. Regulations promulgated in December of that year imposed an aggregate limit on wages and salaries to hospital employees and an aggregate expense limit on new technology. Increases in physicians' fees were prohibited for ninety days and restricted thereafter. Studies of the effects of the Nixon-era cost control program yielded mixed results. Some concluded that the cost control program had resulted in overall cost increases, while others showed a slight decrease in the cost per admission. ${ }^{40}$ The program expired by its own terms on April 30, 1974.

IV

\section{SETTING THE STAGE FOR MARKET-BASED REFORM}

Scholars and some legislators proposed market reform as a means to address problems of health care spending and access. At that time, barriers to competition existed that would have to be addressed if market-based reform were to achieve its goals. Organized medicine had long discouraged competition among physicians and had used its considerable influence to shape financing mechanisms that discouraged cost-based competition among physicians and preserved fee-for-service payment mechanisms. State laws impeded the development of alternative delivery systems. ${ }^{41}$ The so-called "corporate practice of medicine" doctrine limited the ability of corporate entities, especially for-profit

36. Enthoven, Health Plan, supra note 20, at 167-70.

37. $I d$.

38. See Enthoven, Theory and Practice, supra note 22, at 66-67.

39. The Clintons' managed competition plan was to suffer the same fate.

40. Enthoven, Health Plan, supra note 20, at 95-97 (discussing the Economic Stabilization Program and studies of its effects on hospital spending).

41. See Clark Havighurst, Remarks on State/Federal Legal Relationships, Proceedings of the Lawyers' Conference on Health Maintenance Organizations, Group Health Association of America, Inc. 55-56 (Aug. 20-21, 1971). 
entities, to employ physicians to practice medicine. In the absence of explicit legislation authorizing the development of alternative delivery systems that could combine coverage with care, state insurance regulators likely would attempt to enforce insurance laws against these new hybrid entities.

For a time, even federal law discouraged competition in health care. In 1974, Congress enacted the National Health Planning and Resource Development Act ("NHPRDA"). ${ }^{42}$ That statute required states to establish health planning oversight agencies to consider requests for substantial spending on health care resources and to grant or deny certificates of need that were required by the legislation. Although the process proved ineffective both at substantially increasing access in underserved areas and at controlling health care spending, it did empower the quasi-public health planning agencies to favor established providers over new market entrants, even when the new entrants offered greater efficiency. ${ }^{43}$

A series of events in the 1970s paved the way for the market-based reform that would lead to the managed care era a decade later. In 1973, acting on the recommendations of health care scholars, Congress enacted the federal Health Maintenance Organization Act, giving its imprimatur to alternative methods of delivery and financing health care services. Shortly thereafter, it granted these fledgling organizations an exemption from federally mandatory health planning and certificate of need requirements, ${ }^{44}$ evincing its willingness to rely on market forces to allocate health care resources. Perhaps inadvertently, through the enactment of the Employee Retirement Income Security Act of 1974 ("ERISA"), Congress also paved the way for market participants to engage in innovative cost containment activities by limiting the ability of the states, and private plaintiffs proceeding under state law, to impede these private mechanisms to control health care spending. ${ }^{45}$

A less obvious, but no less sentinel, development originated in the judicial branch. In the 1975 case Goldfarb v. Virginia State Bar, the United States Supreme Court rejected a "learned profession" exemption to the federal antitrust laws. ${ }^{46}$ This ruling empowered the Federal Trade Commission to enforce federal antitrust laws against physicians. Such enforcement would undercut the ability of physician associations to continue their previously successful efforts to ensure professional dominance of and to prevent competition in health care

42. 42 U.S.C. $\$ \S 300 \mathrm{k}-300 \mathrm{n}-6$ (1974). The statute was repealed in 1986, although some states have retained the basic health planning structure established under the Act.

43. Enthoven, Health Plan, supra note 20, at 102-05; see also Paul M. Ellwood, JR., The HEALTH MAINTENANCE STRATEGY 19 (1970) (on file with authors) (opining that community planning groups lack insight and authority to resolve national problems and might become advocates of the status quo, thereby impeding basic reforms).

44. Health Planning and Resources Development Amendments of 1979, Pub. L. No. 79-96, 92 Stat. 592.

45. The Employee Retirement Income Security Act of 1974 ("ERISA") provided limited remedies for challenges to health plan decisions about resource use and preempted state laws and state common law causes of action that related to employer-sponsored health benefit plans. 29 U.S.C. $\$ \$ 1001-1461$.

46. 421 U.S. 773 (1975). 
delivery and financing. Four years later, in 1979, Congress rejected an effort by President Carter to re-institute regulatory price controls on hospitals, effectively ending the almost decade-long effort to effect change through comprehensive government control of health care. ${ }^{47}$

As the potential for market-based reform of health care became a reality, the quest for universal coverage faded from the forefront of the national agenda. If the past is the best predictor of future events, the abandonment of national health insurance schemes in the late 1970s in favor of private initiatives should have been predictable. The United States had long declined to follow the lead of other modern welfare states in developing a comprehensive national health program, instead relying on a patchwork of private insurance and public programs to provide health care coverage. Nothing on the social or political horizon of the time could have caused such a significant shift in national policy. The national trend was in the opposite direction: When health reform was under active debate in Congress, the nation had begun to grow skeptical about the results that could be achieved through government regulation. The trend toward deregulation was underway in a variety of industries. Moreover, there was widespread sentiment that universal health care coverage was not economically feasible. ${ }^{48}$ Only a few short years after Medicare and Medicaid expanded access to health care coverage, the need to control health care cost inflation was obvious. $^{49}$ Expanding the then-current style of medical practice to an everincreasing number of citizens would cost more than the nation was willing or able to pay. ${ }^{50}$

\section{USING MARKET INCENTIVES TO REFORM HEALTH CARE: THREE VARIATIONS ON A THEME}

Early proponents of market-based reform of the health care industry did not speak with one voice about the goals of market-based reform or the methods likely to achieve them. Paul Ellwood and the InterStudy Group advocated the use of market forces as an impetus to physicians and other health care professionals to reorganize the methods by which medical services were delivered. ${ }^{51}$ Expanding on the work of the market "re-organizers," health care economist Alain Enthoven focused on targeted government intervention as a means to

47. See Hearing on H.R. 5740, supra note 19.

48. This view was not uniformly accepted. Alain Enthoven argued that Americans were already paying for national health insurance, without getting the benefits of universal coverage due to an inefficient, inequitable system. See Alain C. Enthoven, Consumer-Choice Health Plan (First of Two Parts), 298 NEW ENG. J. MED. 650, 653 (1978) [hereinafter Enthoven, Consumer-Choice, First].

49. See Joseph L. Dorsey, The Health Maintenance Organization Act of 1973 and Prepaid Group Practice Plans, 13 MED. CARE 1, 1 (1975) (early experience with government-sponsored programs indicated that steps would have to be taken to control cost inflation).

50. See McClure, Medical Care System, supra note 16 (noting that cost containment was inevitable).

51. See infra text accompanying notes 55-59, 61-66. 
address market failures and to influence the behavior of market participants to achieve broader socially defined goals. ${ }^{52}$ He formulated a vision of managed competition, which would years later be reexamined by the Clinton administration in its reform proposal. ${ }^{53}$ Finally, drawing on the work of neo-classical economics, market theorists recommended the reform of health care delivery and financing through consumer choice in a competitive marketplace. Clark Havighurst, writing in this Symposium, was a principal spokesperson for this approach.

\section{A. Using Market Forces to Reform Health Care Delivery}

Paul Ellwood, a physician and founder of the Jackson Hole Group, was the first to propose the use of competitive forces to reform the organization of health care delivery. Harking back to early prepaid group practices, he recommended the formation of a new institutional design that would combine the health care delivery and financing functions into a single entity. He first called these new institutions "medical care corporations" and later coined the term "health maintenance organization." ${ }^{54}$ His strategy was initially formulated during a period when the nation's attention was again drawn to national health insurance. Ellwood predicted that national health insurance would worsen the escalation of health care spending that followed the enactment of Medicare and Medicaid and would exacerbate the maldistribution of medical resources, both of which had been identified during the Nixon administration as components of the impending health care crisis. Accordingly, his plan focused on reorganizing the delivery of health care services to meet the needs of an increasing number of Americans while remaining within fiscal constraints. ${ }^{55}$

Ellwood identified three key factors to his proposal for market-based reform of the health care delivery system. ${ }^{56}$ First, physicians would have to organize themselves into separate closed and competing groups. Comprehensive health care services would be delivered through these integrated medical care organizations, replacing episodic care delivered by individual caregivers and institutions. The evolution from the existing fragmented delivery system would provide opportunities for systematic planning and management of health care resources that would bring rationality to health care spending. ${ }^{57}$ The integration across medical specialties would also create opportunities for improve-

52. See infra text accompanying notes 70-88.

53. Marc A. Rodwin, Managed Care and Consumer Protection: What are the Issues?, 26 SETON HALL L. REV. 1007, 1022 (1996).

54. See, e.g., Ellwood, Change in Methods, supra note 30, at 551; Ellwood, Concept, supra note 25, at 29 .

55. Paul M. Ellwood, Jr. \& Walter McClure, Health Delivery Reform, Interstudy Memorandum (1976) (on file with authors) ("[T]here is a significant danger that NHI will seriously aggravate medical cost escalation and the mal-distribution of health manpower and facilities if a health delivery system strategy is not an integral part of its design.").

56. Ellwood, The HeAlth MAintenAnCE STRATEGy, supra note 43, at 12-14.

57. Paul M. Ellwood, Jr., Health Care: Should Your Company Buy it or Sell it?, 14 J. OCCUPATIONAL MED. 667, 671 (1972). 
ment in the quality of care provided to patients through readily available specialty consultation and enhanced opportunities for peer review. Physicians could also benefit from in-place coverage arrangements and improved access to capital.

Second, these organized systems would serve voluntarily enrolled individuals who would elect to receive their health care through a single system for a defined period, thus creating a linked community of patients and providers. Providers would be held accountable for meeting health care needs at the group as well as the individual level. Consumers who did not wish to enroll in a comprehensive-care plan could select a conventional insurance plan. Consumer selection among the integrated entities and between a comprehensive-care model and conventional insurance would introduce competition among physicians. Ellwood anticipated that consumers would make their choices based on the quality of care, level of service, and price, requiring physicians to be responsive to all three variables. ${ }^{58}$

Third, the price for the comprehensive health care services delivered through these newly integrated systems would be fixed and set in advance. ${ }^{59} \mathrm{~A}$ fixed predetermined income would reverse the existing incentives of fee-forservice medicine to provide ever more services. The price charged to consumers would reflect the efficiency of the caregivers participating in the system. Fiscally responsible organizations would be rewarded because consumers would be attracted to their lower premiums. Because consumers would be prepaying for care from an identified group of caregivers, rather than for indemnification against the cost of care that they would have to find themselves, they would be assured of access to needed health care services.

Although these fully integrated arrangements formed the backbone of Ellwood's proposal for reforming health care delivery, he also foresaw that thirdparty payers or employers might form looser health care alliances with selected individual and institutional providers to deliver comprehensive medical services to their constituents. In such arrangements, the payer or employer-organizer would bear the ultimate financial responsibility for the cost of care. Payers would therefore have an incentive to select only efficient providers to render services; providers, in turn, would strive for efficiency to secure their place within the selected group. ${ }^{60}$

The federal government's role in market-based reform would be to encourage, and to remove legal barriers to, the development of alternatives to the existing distinct delivery and financing systems. ${ }^{61}$ The market power of the

58. See Ellwood \& McClure, supra note 55, at 3.

59. The Institute of Medicine stated that the key characteristic of health maintenance organizations was fixed payment, because it was fixed payment that created financial risk and financial risk that created incentives to avoid excessive cost and unnecessary services. See InSTITUTE OF MEDICINE, HEALTh MAINTENANCE ORgANIZATIONS: TOWARD A FAIR MARKET TEST 3 (1974) [hereinafter INSTITUTE OF MEDICINE].

60. See Ellwood \& McClure, supra note 55, at 4-5.

61. Ellwood, The Health Maintenance Strategy, supra note 43, at 17-20. 
government-as-purchaser could ensure that only organizations with sufficient fiscal and professional resources would be allowed to participate in offering their services to government beneficiaries. Although competition and consumer choice would be the hallmarks of the system, Ellwood suggested that government mandates might be used to force employers to offer employees choices among conventional insurers and alternative delivery systems, and tax incentives could be devised to encourage consumers to select more efficient delivery options.

Ellwood expressed high hopes for the achievements of competition among conventional means of coverage and newly created organizations that combined care and coverage. As physicians were encouraged to form integrated systems to compete for consumers' business, health care organizations would change the landscape of small entrepreneurial medicine. To keep costs of comprehensive care packages competitive, physicians would eliminate wasteful medical services and would replace clinical variation with medical services of uniform quality. ${ }^{62}$ Thus, competition among integrated systems that were accountable for care and coverage would improve health care quality. Competitive opportunities in medically under-served areas would address issues of maldistribution of health care manpower. To control health care spending, physicians would depart from the patient primacy directive that had long characterized medical ethics to embrace a duty to populations of patients. ${ }^{63}$ Any tendency to err unduly on the side of the group of patients would be deterred by traditional medical ethics and the competitive necessity to satisfy individual consumers.

There were reasons to approach Ellwood's proposal cautiously. Closed panel, prepaid health care had long been beset with the hostilities of organized medicine, whose successful lobbying efforts had translated into significant legal hurdles to its development in many states. One of the earliest prepaid plans, Kaiser Foundation Health Plan, warned that the theoretical benefits attributed to a proposed shift to prepaid practice exceeded the gains that could be validated. ${ }^{64}$ When Ellwood and others began to focus on prepaid medical practice as a solution to the nation's health care spending and medical care access problems, prepaid group practice plans and health care foundations, principally clustered on the east and west coasts, served fewer than five million citizens. ${ }^{65}$ Those citizens were not representative of the overall population. The industry had developed in response to employers' desire to bring health care services to workers and their families assigned to remote locations. ${ }^{66}$ If these new market

62. See Ellwood, Change in Methods, supra note 30, at 551 (reformed health care industry will produce goods and services of uniform quality nationwide and will order those services at reasonably stable prices).

63. See Enthoven, HeAlth Plan, supra note 20, at 140-41 (medical care costs will be controlled by the judgment of physicians, because they will accept responsibility for managing the total health care costs of enrolled patient populations).

64. Somers \& Somers, Major Issues, supra note 26, at 201 (noting Kaiser's protest).

65. See Dorsey, supra note 49, at 9.

66. Thomas Mayer \& Gloria Gilbert Mayer, HMOs: Origins and Development, 312 NEW ENG. J. MED. 590 (1985). 
entrants were to assume a dominant role in a reformed health care system, they would have to serve a heterogeneous population. The differences between the economic preferences of underserved working populations, which were the niche of prepaid care, and affluent suburbanites, accustomed to the indemnity insurance model, likely exceeded their similarities. Moreover, the chronically ill, the disabled, and the elderly were underrepresented in the prepaid working population that was the model for scholars' suggested market reforms.

There were also reasons for optimism about a prepaid group practice model. The limited data available from the prepaid practices in the early 1970s showed considerable promise in their ability to control health care spending. Integrated systems for delivery of health care services allowed health care organizations to take advantage of economies of scale and to eliminate duplication of services. Prepaid plans delivered care at less cost and paid a greater percentage of that cost than conventional health insurance. ${ }^{67}$ Lower cost was achieved in part because patients in prepaid plans used fewer hospital services and received a wider range of care in a less costly outpatient setting than did patients with conventional insurance. ${ }^{68}$ In some cases, physician-sponsored prepaid health care delivered services at a cost twenty-five to thirty percent below the cost of care delivered through the dominant health care delivery system. ${ }^{69}$

Integrating health care delivery systems also offered potential to improve the quality of medical care. In a closed system with a constant patient population, peer review processes could evaluate physicians' performance across a full spectrum of care and on the basis of a single medical record. Having a defined population of patients would permit the physician to seek out the individual patient for preventive care and to monitor compliance with treatment regimes. It would also facilitate the evaluation of medical outcomes across a sizeable population of patients, leading to clinical improvements as both best practices and problems were identified. The system would reap the financial benefits of its improved organization and management, and the system's enrolled population would reap the health benefits of preventive services and coordinated comprehensive medical care as well as share in the savings through lower premiums. $^{70}$ To Ellwood, a physician by training, the potential for improved quality at lower cost, coupled with the opportunity to avoid extensive public regulation of medical practice, proved persuasive.

67. Avedis Donabedian, An Evaluation of Prepaid Group Practices, 6 INQUIRY 3, $12-14$ (1969) (reporting that the lowest utilization rates occurred under prepaid group practice plans, and the highest rates occurred under indemnity plans).

68. Id.; see also Regina Herzlinger, MARKet Driven HeAlth CARE: Who Wins, WhO LOSES IN THE TRANSFORMATION OF AMERICA's LARGEST SERVICE INDUSTRY 116-17 (1997) ("HMO members generally experience lower hospital admission rates and lengths of stay.").

69. Alain C. Enthoven, A System Gone Astray, at http://www.docrates.net/feature/enthoven.htm (last visited Feb. 28, 2002) [hereinafter Enthoven, Astray].

70. See generally Walter McClure, National Health Insurance and HMOs, 21 NuRsING OUTLOOK 44, 47-48 (1973) (describing how health maintenance organizations would improve quality). 


\section{B. Managed Competition and the Consumer Choice Health Plan}

In a system he would later characterize as a "prescription" for health care reform, Alain Enthoven proposed targeted government intervention to create a regulated medical marketplace. ${ }^{71}$ If the perverse incentives of the pre-managed care system could be traced to tax incentives and payment practices adopted by private insurers and government payers, redress could come in the form of limited government regulation aimed at changing those incentives and stimulating competitive forces. ${ }^{72}$ His proposed interventions addressed long-recognized market failures in health care: consumers' lack of information and choice. In addition, he proposed interventions to restrain private payers from engaging in competitive practices that would be inconsistent with achieving broader social goals.

Enthoven agreed with Ellwood's recommendation that closed competing physician organizations should be the predominant form of health care delivery in a reformed medical marketplace. ${ }^{73}$ But he had a more diverse vision of the forms that physician organizations might take, including: prepaid group practices, the model for Ellwood's medical care organizations; individual practice associations, which closely resembled Ellwood's health care alliances; and primary-care physicians acting as care managers for their patients. ${ }^{74}$ The primary organizational element was to be closed competing units of physicians selling their services at charges that reflected each unit's ability to control costs. ${ }^{75}$

While incentives for economy would be a key factor in his vision for reform, Enthoven foresaw an "enhanced role for physicians" in controlling health care spending beyond their own services. ${ }^{76}$ They would be required to "set priorities, look at alternatives and make hard choices." sicians would create and use comparative data about cost and quality, advanced production technology to improve quality and productivity, better organizational and management techniques to coordinate care and reward wellness, and outcomes research to improve clinical care. ${ }^{78}$ Enthoven and Ellwood seemed to assume that changed financial incentives and government encouragement of alternative delivery models would lead inexorably to provider-initiated change

71. See Alain C. Enthoven, The Fortune 500 Model for Health Care: Is Now the Time to Change?, 27 J. Health Pol. POL'Y \& L. 37 (2002) [hereinafter Enthoven, Fortune 500] ("[M]anaged competition was not intended to be a 'theory'.. It was a prescription.") (emphasis in original). See generally Alain C. Enthoven, The Need for Fundamental Reform through Competition and Rational Economic Incentives, ISSUES IN HEALTH CARE (1981) [hereinafter Enthoven, Fundamental Reform].

72. See Enthoven, Consumer-Choice, First, supra note 48, at 651-52.

73. Alain C. Enthoven, Consumer-Choice Health Plan (Second of Two Parts), 298 NEW ENG. J. MED. 709, 709 (1978) [hereinafter Enthoven, Consumer-Choice, Second].

74. Id. at 710 .

75. Alain C. Enthoven, Health Care Costs: Why Regulation Fails, Why Competition Works, How to Get There from Here, NAT'L J. 885, 887 (May 26, 1979).

76. Alain C. Enthoven, The Economic Future of Health Care, 21 AM. PHARMACY (n.s.) 18, 21 (Aug. 1981).

77. Alain C. Enthoven, Shattuck Lecture-Cutting Cost Without Cutting the Quality of Care, 298 NEW ENG. J. MED. 1229, 1229 (1978).

78. Ellwood, Change in Methods, supra note 30, at 555. 
in the delivery system, and that traditional physician values would prevail in this reformed delivery system. ${ }^{79}$

Like Ellwood's proposed reforms, Enthoven's plan for system-wide market reform relied on consumer choice among the competing delivery systems and the traditional fee-for-service sector, which, under his vision, would be greatly diminished in size and importance relative to the most cost-effective delivery models. To ensure that consumers were informed about their choices, Enthoven proposed that the federal government intervene to require that market participants provide uniform data in an understandable format. Consumer choice would be ensured by giving each family an annual choice of all or a significant number of competing private health care financing and delivery plans, including both prepaid plans and conventional insurance plans. Enthoven initially recommended that the link between employment and health care coverage be severed. ${ }^{80}$ Later, he would retreat from the individual-choice model, concluding that sponsors for groups of individuals were a more efficient means of ensuring competition for health care coverage. ${ }^{81}$ A substantially similar guarantee of consumer choice could be ensured by group purchasers' offering a range of choices to group enrollees.

Market reform, however, could not be entrusted to informed consumers who did not have a financial stake in the decisions. Rather, consumers would have to be provided with financial incentives to make wise economic choices. Enthoven's answer was the fixed dollar subsidy. ${ }^{82}$ He offered different proposals for how these incentives might be created. Under a national health insurance approach, each family could receive a fixed dollar amount of financial assistance to pay toward its choice, ensuring that consumers would participate in savings generated by efficient caregivers. Increased financial support from public funds would be available only to the indigent. ${ }^{83}$

Another strategy to create consumer incentives would rely on reform of existing federal tax laws. ${ }^{84}$ Each taxpayer would receive a fixed-amount refundable tax credit based on the actuarial cost of providing care to individuals in the taxpayer's age-gender cohort. The indigent would receive vouchers based on their family incomes to spend on qualified plans of their choice. Medicare beneficiaries would also be permitted to direct payment to a qualified plan of their choice. While individuals at higher risk for incurring extensive medical expenses, who therefore would incur higher premium costs, would have the benefit of a larger tax credit, individuals who merely selected higher cost coverage alternatives would bear the full economic brunt of their costly choices.

79. See, e.g., Ellwood, Concept, supra note 25, at 29-30 (government should foster voluntary change by providers to improve the delivery system to respond to consumer needs).

80. See generally Enthoven, Fundamental Reform, supra note 71.

81. See Enthoven, Fortune 500, supra note 71, at 46 (recommending that corporate purchasers create incentives for consumers and providers to make economical choices).

82. ENTHOVEN, HeAlTH PlAN, supra note 20, at 123.

83. Id. at 123-24.

84. See Enthoven, Consumer-Choice, Second, supra note 73, at 711-12. 
Government intervention would also be used to address failures in the market for health care coverage and to ensure that the competitive marketplace was organized in a manner intended to achieve social goals. To ensure fairness among competitors, all insurers and health plans would be subject to the same rules. Because universal coverage had been identified as a primary social aim, each competitor would be required to accept all individuals who wished to enroll. $^{85}$ The federal government would oversee the annual open enrollment pro-cess, ensuring that payers could neither compete on the basis of risk selection nor engage in discrimination against the elderly, the poor, and the sick. While Enthoven was not in favor of a single benefit design, preferring instead to create competition on that basis, he would require that every competitor offer a low option limited to nationally defined basic benefits. ${ }^{86}$ Each competitor would set its own premium based on the cost of providing care in its market area, and each insurer or health plan would be required to charge the same premium to all individuals in an actuarial category and to provide the same benefits in exchange for that premium. Out-of-pocket expenditures would be subject to an annual maximum, and beyond that amount, the payer would be required to cover all the cost for all covered services. The result would be an explicit crosssubsidization of the sick by the healthy, a premise readily accepted in Europe but historically viewed with disfavor in this country. Later, Enthoven would explain that an unregulated "free market of health plans and individual consumers is likely to be characterized by some combination of high premiums, poor coverage..., and discrimination against the sick." ${ }^{87}$ His words would prove prophetic, as regulatory missteps inhibited market-based reform targeted to achieve social goals.

\section{Creating a Competitive Market for Health Care Services and Coverage}

In keeping with the precepts of neoclassical economics, Clark Havighurst and other market theorists recommended that the medical marketplace should be entrusted to consumers who could choose among a wide range of health care financing and delivery options. Neither the prevailing indemnity model nor the proposed HMO model offered low-cost options to consumers who might wish to economize on the use of health care services. ${ }^{88}$ Under truly competitive conditions, profit-oriented physicians and payers would offer those products and services desired by consumers and deliver them in the least costly manner possible. Innovation to satisfy different consumer preferences would expand the choices offered. Medicine, like the rest of the national economy, would reflect and respond to consumers' diverse preferences.

The market theorists agreed with Ellwood and Enthoven that consumers

85. ENTHOVEN, HEALTh Plan, supra note 20, at 120-21.

86. $I d$.

87. Enthoven, Theory and Practice, supra note 22, at 74.

88. See Clark C. Havighurst, How the Health Care Revolution Fell Short, 65 LAw \& CONTEMP. PROBS. 55 (Autumn 2002). 
would have to be given a choice within a range of health coverage designs, ${ }^{89}$ that they would have to have financial stake in their decisions, and that tax law that distorted consumers' financial incentives would have to be changed. ${ }^{90}$ The principal point of departure between the Ellwood model and the market theorists' vision for market-based reform was the role assigned to newly integrated units of physicians. ${ }^{91} \quad$ Two design options, indemnity coverage and prepaid care offered by a small number of competitors, would not offer the same benefits for market-based reform of health care as more intense competition. Market theorists recommended that health maintenance organizations and other organized systems for combining the delivery and financing functions be given a "fair market test" as one competitor in a pluralistic marketplace. ${ }^{92}$ The benefit of these new market entrants would not be as a replacement for the prevailing dominant fee-for-service system, but as a cost constraint on physicians and a stimulant to innovation throughout the medical marketplace. The introduction of new competitors would cause both providers and third-party payers to respond by creating new methods of delivering and financing health care services.

Market theorists also had a more pragmatic view about the ease with which closed integrated units of physicians would be formed. Havighurst predicted that health maintenance organizations and prepaid group practices would be difficult to organize and initiate; they would require capital, commitment from groups of like-minded caregivers, and time. Moreover, they might not be as attractive to consumers as other benefit designs. Consumers accustomed to less directive forms of health care delivery might be reluctant to enroll in them or to abandon longstanding physician relationships in order to do so. ${ }^{93}$

Compared with other proponents of market reform, market theorists' views were less directive. While the contours of the medical marketplace would no longer be static, as they had been in the era of fee-for-service medicine financed by passive insurers, neither could they be dictated, nor even foretold. Consistent with economic principles, the mix of health care delivery and financing vehicles would be determined over time through the decentralized decisions of informed consumers.

89. In keeping with his multiple-choice concept, Havighurst recommended that at least one of the choices offered to a consumer should be a "cost sensitive health plan," which could include closed panel plans as well as plans that structured benefits to include consumer cost sharing. See Hearing on H.R. 5740, supra note 19 , at 139.

90. See id. at 129-30.

91. See Clark C. Havighurst \& Glenn M. Hackbarth, Private Cost Containment, 300 NEw ENG. J. MED. 1298, 1298 (1979) ("Our analysis differs from common conceptions of the market strategy in that we anticipate a greater role for private health insurance and a comparatively less central role for the prepaid-group-practice variety of HMO.").

92. See generally INSTITUTE OF MEDICINE, supra note 59.

93. See Clark C. Havighurst, Health Maintenance Organizations and the Health Planners, 1978 UTAH L. REV. 123, 126-29 (1978). 
VI

\section{The Political PATH TO MARKET-BASEd REFORM}

President Nixon and his senior health policy team were anxious to find a private sector approach to health care cost control. Influenced by scholars' recommendations, they embraced the model of the largest prepaid group practice, the Kaiser-Permanente Medical Care Group Program, which, like Nixon and his senior health advisors, had its roots in California. ${ }^{94}$ Some prepaid group practice industry experts, however, were skeptical of the administration's goal to move prepaid group practices from an alternative form to the mainstream of the health delivery system. Many of their fears were later to be realized.

Industry experts believed that, if indemnity insurers and health care providers sponsored health maintenance organizations, the principles that served as the foundation for prepaid group practice would not survive. ${ }^{95}$ These principles-not-for-profit status, community-based premium rating, comprehensive benefits with little patient cost-sharing, and a rigid adherence to the prepaid group practice organizational structure-were not entirely consistent with a competitive marketplace agenda. Moreover, most physicians did not practice in a manner consistent with the prepaid multispecialty group model, which was based on quality control mechanisms that required careful selection of physicians who would work in concert. ${ }^{96}$

The prepaid group-practice sector was also committed to dual choice: allowing consumers to choose between prepaid group practice plans and traditional insurance. ${ }^{97}$ Enrolling in prepaid group practice plans involved tradeoffs that would not be acceptable to many consumers, foremost among them having to select a physician who was part of the group. Offering potential enrollees a choice of plan design countered the criticism that prepaid group practice plans did not provide free choice of physicians. ${ }^{98}$ Kaiser-Permanente, for example, would participate in a group health benefits plan only if the prospective enrollees were given a choice of benefit design. ${ }^{99}$ If prepaid group practice

94. See Hearings on H.R. 5615, supra note 27 (statement of Richard M. Nixon, President of the United States) ("[The] new approach has two essential attributes. It brings together a comprehensive range of medical [services] in a single organization ... [a]nd it provides needed services for a fixedcontract fee that is paid in advance.... [T] hey increase the value of services a consumer receives for each health dollar.").

95. Howard Veit, coauthor of this article, was Director, Office of Health Maintenance Organizations, from 1978 to 1981. In 1975, he served as a consultant to the federal HMO program. During this period, he held several meetings with officials at Kaiser Permanente and with members of the Board of the Group Health Association of American, during which they expressed grave concerns that the federal HMO program encouraged sponsorship by organizations that would not sustain the principles of prepaid group practice.

96. See Response of Western Clinic of Tacoma, Wash., to congressional inquiry about methods to assure quality care in health maintenance organizations. Health Maintenance Organizations: Questions and Answers Relating to Subcommittee Questionnaire, Subcomm. on Health of the Comm. on Labor \& Pub. Welfare, United States S. 59 (Mar. 1972).

97. Jerry Phelan et al., Group Practice Prepayment: An Approach to Delivering Organized Health Services, 35 LAW \& CONTEMP. PROBS. 796, 799 (Autumn 1970).

98. Id. at 799-800.

99. Id. at 799 . 
became the predominant means of health care delivery, as health reform proponents suggested, the dual choice concept would be in jeopardy. Congress seemingly paid little heed to many of these concerns. The federal Health Maintenance Organization Act of 1973 ("HMO Act") was its first attempt to change the underlying structure of health care delivery through the targeted use of market forces. ${ }^{100}$ While reform-minded federal legislators seemed to assume that the prepaid group practice model would dominate the new industry ${ }_{101}^{101}$ the Act permitted deviations from that model. For example, prepaid group practice advocates were concerned about granting federal qualification status to Individual Practice Association ("IPA") models for health maintenance organizations. IPAs were loosely affiliated networks of mostly solo practice, fee-for-service physicians that did not offer the integration of clinical services or acceptance of financial risk that characterized prepaid group practice. The American Medical Association and IPA lobbyists, however, argued successfully that physicians would never embrace the HMO concept unless the HMO Act included IPA model HMOs. ${ }^{102}$

As many in the prepaid group practice community had predicted, the HMO Act proved to be a mixed blessing. The Act provided many benefits to the industry. It made start-up funds available to encourage the development of alternatives to indemnity insurance and fee-for-service medicine. To finance a five-year demonstration program, \$325 million was authorized for fiscal years 1974 through 1977. ${ }^{103}$ The Department of Health, Education and Welfare created an office to assist in the start-up and operations of health maintenance organizations. $^{104}$ The HMO Act also protected federally qualified health maintenance organizations from state laws that would hamper their growth, while giving the states substantial latitude to develop legislation that would enable a wide range of organizational forms. ${ }^{105}$ Despite its loss to the AMA on

100. See Dorsey, supra note 49 , at 1 (previous laws were directed at purchase, planning, and resource availability.).

101. When the Senate Subcommittee on Health prepared a questionnaire about health maintenance organizations, those asked to respond included seven direct medical services providers, the Blue Cross and Blue Shield associations, and several trade associations. See Health Maintenance Organizations: Questions and Answers Related to Subcommittee Questionnaire, Subcomm. on Health of the Comm. on Labor \& Pub. Welfare, United States S. 59 (Mar. 1972). The prepaid groups included Family Health Plan of Southern California, Group Health Cooperative of Puget Sound, Kaiser Foundation Health Plan, Western Clinic of Tacoma Washington, Harvard Community Health Plans, and the Harvard Center for Community Health. The associations included the Group Health Association, Federation of American Hospitals, American Nurses Association, American Society of Medical Technologies, and the American Medical Association.

102. Health Maintenance Organization and Resources Development Act of 1972, S. REP. No. $92-$ 978 (July 21, 1971) (describing the AMA testimony that the HMO concept should be defined flexibly to include a variety of organizational forms, including the IPA and foundation model).

103. See Comptroller General's Report to Congress, Factors that Impede Progress in Implementing the Health Maintenance Organization Act of 1973 (Sept. 3, 1976).

104. The performance of this office was later subject to criticism for lack of coordination, inadequate staff resources to carry out its charge, and inexperience with promulgation of regulations. See id. at 11-20.

105. At the time of the passage of the HMO Act, three categories of state laws were viewed as impediments to the development of HMOs: medical society approval to furnish medical services, 
the IPA issue, the fledgling HMO industry was not without its own lobbying successes. The Group Health Association of America successfully made the case to Congress and the Administration that without some legislative coercion, HMOs would never be included in employee health benefits plans, employees would not be exposed to them, and the federal HMO initiative would fail. As a result, the Act included a mandated dual choice option, which gave federally qualified health maintenance organizations the ability to mandate their way into the marketplace for health care coverage by enabling them to require that certain employers offer a managed care option to their employees. ${ }^{106}$

The HMO Act imposed conditions on federally qualified HMOs that would not have evolved in a competitive marketplace, which were to prove detrimental to the HMO industry in its early years. These requirements were similar to those later recommended by Alain Enthoven, with one significant difference: They applied only to health maintenance organizations that elected to pursue federally qualified status. The Act mandated an annual open enrollment period during which an HMO would be required to take all applicants. ${ }^{107}$ As a result, high-risk individuals would have easier access to federally qualified HMOs than to other insurers. Moreover, in keeping with the Nixon Administration's reliance on the Kaiser-Permanente model, it imposed a system of community rating that required premiums to reflect the cost of providing care to the entire community rather than the experience of an enrolled group. ${ }^{108}$ Community rating hampered the ability of federally qualified HMOs to use underwriting practices to compete for groups with more favorable health-usage experience, because such groups could purchase coverage at a lower cost from insurers and managed care organizations that offered experience rating.

The Act established a minimum benefits package that all federally qualified HMOs were required to offer. ${ }^{109}$ The required benefits for federally qualified HMOs closely mirrored the comprehensive benefits offered by Kaiser-Permanente and other prepaid plans that predated the HMO Act. Mandating the use of a rich benefits package, however, inhibited the development of lower-cost plans. Some consumers might have preferred lower-cost plan designs. In addition, low-cost plans could have contributed to the achievement of near universal

physician representation on the HMO's governing body, and insurer capitalization and insolvency reserves. See id. at 28-29.

106. See A Quarter Century of Health Maintenance, 280 JAMA 2059 (1988).

107. HMO Act of 1973, 42 U.S.C. $§ 300$ e; see 42 U.S.C. $\$ 300 \mathrm{e}-9$. All employers subject to the Fair Labor Standards Act and employing twenty-five or more employees were required to offer their employees the option to enroll in a health maintenance organization, when a federally qualified health maintenance organization exercised its right to "mandate" that the employer do so. This section came to be known as the "dual-choice" provision.

108. 157 Pub. Law No. 93-222, § 1301. The Secretary could waive the open enrollment period if it would jeopardize an HMO's economic viability. The Comptroller General found that fifty-six percent of HMOs surveyed said that the open enrollment requirement hurt their competitive position. Comptroller General's Report to Congress, supra note 103, at 31.

109. See John K. Iglehart, HMO Act Changes Advanced to Bolster Troubled Program, NAT'L J. 1161, 1165 (Aug. 16, 1975) (quoting Walter McClure's observation that health maintenance organizations alone cannot solve social problems with coverage for those with high medical costs). 
coverage by making coverage affordable to a wider range of groups and individuals.

The Act also limited the annual amount that patients could be charged through copayments. This limitation imposed an administrative burden on federally qualified HMOs. ${ }^{110}$ More importantly, the copayment limit minimized the cost-control effect that could be achieved through patient cost sharing. Although the requirement was consistent with prevailing practices in the prepaid group model, it discouraged product designs that permitted consumers to limit the cost of coverage in exchange for higher out-of-pocket expenditures. Thus, rather than encouraging innovation and expanding consumer choice, when it was enacted the HMO Act was poised to have the unintended consequence of impeding innovation and thereby hampering its potential to create marketplace competition.

The implementation of the HMO Act sputtered for several years after its enactment, due partly to the Act's burdensome requirements and partly to bureaucratic mismanagement. In 1976, the HMO Act was amended to ameliorate some of the onerous effects of these provisions. ${ }^{111}$ The open enrollment requirement was limited to HMOs that had been operational for at least five years or those that had at least 50,000 enrollees and were not operating at a financial deficit. ${ }^{12}$ Federally qualified HMOs were given four years to adopt a community rating system. ${ }^{113}$ In 1978, Congress again amended the Act to increase federal funds. ${ }^{114}$ The most significant change in the managed care legal landscape, however, was to come inadvertently from the actions of state legislatures. As the states adopted enabling legislation for health maintenance organizations, fewer organizations elected to pursue federally qualified status and subject their operations to the restrictions of the HMO Act. ${ }^{115}$

Many of the HMO Act provisions-open enrollment, minimum benefits, community rating-were consistent with the goal of achieving a "decent minimum" level of coverage for all citizens, or at least all citizens with access to the means to obtain coverage. ${ }^{116}$ Because only federally qualified HMOs were sub-

110. The Comptroller General found that fifty-six percent of HMOs surveyed believed that the comprehensive coverage plan would make federally qualified HMOs noncompetitive. Comptroller General's Report to Congress, supra note 103, at 30.

111. See Dorsey, supra note 49, at 5 (noting that the copayment cap imposed a new administrative burden on prepaid group plans and undermined the traditional benefit of reduced paperwork).

112. Health Maintenance Organization Amendments of 1976, Pub. L. No. 94-460, 90 Stat. 1945 (1976).

113. Id. at 1946.

114. Id. at 1947.

115. In March 1978, the Carter Administration, represented by Joseph Califano, then Secretary of Health, Education, and Welfare, convened a meeting of business and labor leaders from around the country to unveil the Administration's HMO initiative and to generate support for its approach. During the Carter years, co-author Veit, along with DHEW officials, spoke at employer and union meetings to encourage support for HMO growth. See JOSEPH A. CALIFAnO, JR., Governing AMERICA 167 (1981).

116. By June 1976, only seventeen HMOs had been federally qualified, twelve of which had been assisted by federal loans through the HMO Act of 1973. Comptroller General's Report to Congress, supra note 103 , at 6. 
ject to the Act's requirements, their competitive position was hampered vis-àvis coverage providers beyond the Act's reach. Since the federally mandated benefit package was more generous-and thus more expensive-than others offered to the same population, federally qualified HMOs were subject to biased selection. High-need users of health care services would be more likely to select a federally qualified HMO, weakening their economic position. ${ }^{117}$ The higher cost of coverage would dissuade employers from offering federally qualified HMOs to their employees. And individuals would be able to afford personal coverage. Inhibiting the HMO industry's market share and economic success limited its potential to facilitate voluntary market-based restructuring of health care delivery, and also impeded progress toward universal coverage. In short, Congress entrusted a small segment of the health financing industry with the large task of resolving a persistent societal problem and burdened the emerging player with a wish list that was not imposed on other established segments of the industry. ${ }^{118}$

Four years after the passage of the HMO Act, the Carter Administration made HMO expansion a central ingredient in its health care strategy. To generate momentum for the stalled HMO initiative, the Administration needed the active endorsement of employers and unions. In the years immediately following the passage of the HMO Act, the business community did not strongly support its implementation. ${ }^{119}$ Much of its reluctance stemmed from employers' opposition to the mandated dual choice provision of the Act. Most large employers, accustomed to offering their employees a single fully insured or selfinsured indemnity plan, were not eager to include HMOs in their employee benefits plans; their reluctance was exacerbated by a government mandate that they do so. Although employers complied with the letter of the law when approached by HMOs exercising the mandate, they did not encourage employees to join HMOs. The indemnity insurers, with long-standing business relationships with employers, feared competition from HMOs and did little to counter this attitude.

Those friendly to the Carter Administration's initiative had to reverse this trend, and seemingly persuasive arguments were available to them to do so. HMOs would allow unions to preserve broad, collectively bargained health care benefits for their members even in the face of rapidly escalating health care costs. Greater competition among payers would enhance the bargaining position of purchasers of health care coverage, putting employers in a stronger buying position and giving employees more options.

117. "Decent minimum" is Enthoven's term. He defines it as all "“cost-worthy' medical care that can effectively prevent or cure disease, relieve suffering and correct dysfunction." Enthoven, Theory and Practice, supra note 22, at 2. The Act referred to "basic health care services," which reflected current practice rather than an analysis of marginal cost and marginal benefit as Enthoven proposed.

118. See Dorsey, supra note 49, at 4-6.

119. See Iglehart, supra note 109 (discussing factors contributing to problems with health maintenance organization strategy). 
By the early 1980s, new HMOs funded through the HMO Act joined the ranks of those that predated the federal initiative. ${ }^{120}$ Although federally funded HMOs remained far from the mainstream of the health care system, their presence began to generate competition between traditional insurers and HMOs and to influence premium-pricing decisions. Despite their misgivings, physicians and hospitals began to compete for the opportunity to affiliate with successful HMOs. Health care costs continued to escalate. During the decades that followed the passage of the HMO Act, increasing numbers of employees had the opportunity to enroll in HMOs. The managed care revolution was underway.

\section{VII}

\section{LOOKING BACK AT MARKET-BASED REFORM}

After the Reagan Administration came into office in 1981, the federal role in health care market reform began to diminish. The private sector assumed the dominant role in reshaping the health care marketplace. Commercial insurers introduced HMO-like product designs, and many HMOs elected not to seek federally qualified status. States abandoned the laws prohibiting HMOs and replaced them with statutes that regulated HMO operations. As growth in the managed care sector accelerated, states' efforts at regulatory oversight intensified, encouraging more employers to self-insure to avoid costly state restrictions. But purchasers, payers, and providers alike failed to perform as anticipated, and the necessary conditions for true market-based reform failed to materialize.

\section{A. Physicians Resist Change}

Perhaps the greatest failure of the crystal ball into which early health care reformers gazed was its prediction of physicians' responses to efforts to increase competition by changing the financial incentives of medicine. Given the centrality of physician behavior to the early visions for a reformed health care delivery system, surprisingly little attention was directed to physicians and the multiple factors that affected their professional behavior. Clark Havighurst correctly predicted the inherent difficulties in creating prepaid group practices and other integrated physician organizations. ${ }^{121}$ In contrast, Ellwood's colleague, Walter McClure, predicted that most alternative delivery systems to evolve under a competitive regime would be hospital-based multispecialty group practices. ${ }^{122}$ The Mayo Clinic was a frequently mentioned model. ${ }^{123}$ Hospitals and physicians would restructure their activities, McClure opined, as a result of changes in economic incentives and pressures from large group pur-

120. See CALIFANO, supra note 115 , at 166-67.

121. See supra text accompanying note 93.

122. McClure, Medical Care System, supra note 16, at 48-49.

123. Alain Enthoven has reiterated his focus on physician-sponsored medical care, citing the Mayo Clinic as one example. See Enthoven, Astray, supra note 69. 
chasers. ${ }^{124}$ McClure urged that private providers "need simply organize their own delivery plan, enroll their patients, and continue to practice as usual." 125 Faced with limited budgets set in advance, Ellwood's "medical care corporations," based on the prepaid group practice model and dominated by physician values, were presupposed to incorporate clinical values and engage in a coverage version of medical triage to eliminate wasteful and ineffective care. Such systems would serve their enrolled patient populations more cost and clinically effectively. ${ }^{126}$

Victor Fuchs offered the most extensive commentary on the role of the physician in a managed care system. He acknowledged the need for market reform and for supplementing market forces with central control, but urged that more would be achieved through the "custom and tradition that dominate many aspects of medical practice and medical education." ${ }^{27}$ Medical care and society would be better off, he stated, if physicians played a major role in reforming the health care system. ${ }^{128} \mathrm{He}$ recommended that medical schools broaden their curricula to train a "continuum of personnel" and "supergeneralist" physicians who would combine scientific and administrative knowledge and skills. ${ }^{129} \mathrm{He}$ advised physicians to think of health in broad terms and to consider economic consequences in making decisions about staffing, purchasing capital equipment, and expanding facilities. ${ }^{130}$ To achieve market-based reform, Fuchs argued that physicians would have to accept that they must acquire "some sophistication concerning allocation of scarce resources to meet multiple goals." 131

The majority of physicians did not organize themselves into multi-specialty group practices and align with hospitals to provide care and with carriers to provide business acumen, as reform proponents predicted they would. ${ }^{132}$ Fuchs' call for a reform of medical education and an expansion of the medical con-

124. McClure, Medical Care System, supra note 16, at 49-50.

125. Walter McClure, Letter to the Editor, 58 HosP. PROGNOSIS 6, 10 (1977).

126. See Enthoven, Astray, supra note 69 ("I envisioned organizations in which physicians would accept responsibility for managing quality and resource use, organizations that would attract the loyalty, commitment and responsible participation of physicians, and organizations that would partner with health insurers to market their services."). Of course, no one can say with certainty that physicianled organizations would have governed by medical values. Rather, the new medical care organizations may have become more like commercial carriers when they assumed the coverage role simultaneous with the care role.

127. Victor R. Fuchs, What Kind of System for Health Care?, 45 Bull. N.Y. ACAD. MED. 281, 292 (1969) [hereinafter Fuchs, What Kind of System].

128. Victor R. Fuchs, Improving the Delivery of Health Services, 51-A J. BONE \& JOINT SURGERY 407, 412 (1969) [hereinafter Fuchs, Improving the Delivery].

129. Fuchs, What Kind of System, supra note 127, at 290.

130. Id. at 289. Fuchs disavows this economic thinking, however, when physicians are making bedside treatment decisions. Later scholars would concede that economic thinking must invade that realm as well.

131. Fuchs, Improving the Delivery, supra note 128, at 412.

132. See Alain C. Enthoven \& Sara J. Singer, Unrealistic Expectations Born of Defective Institutions, 24 J. HEALTH POL. POL'Y \& L. 931, 937 (1999) (stating that physicians failed to organize themselves to responsibly manage the cost of medical services); see also Marsha Gold, The Changing US Health Care System: Challenges for Responsible Public Policy, 77 Milbank Q. 3, 15 (1999) (noting that only ten percent of physicians practiced in groups of twenty or more in 1996). 
sciousness to population-based allocation of health care resources was not heeded. Instead, traditional insurers offering new managed care benefit designs assumed the dominant role in a managed care system. They engaged in selective physician contracting to exert control over physicians' fees and created incentive-based reimbursement strategies to encourage cost-conscious clinical decision-making. ${ }^{133}$ The contracted physicians, however, were typically not engaged in clinically integrated practices, which undermined their ability to achieve cost savings or quality improvements through the mechanisms used by the prepaid group practices that formed the model for proponents' visions of managed care. Moreover, as the percentage of the population covered by managed care organizations increased, physicians elected to contract with as many carriers as possible to protect their patient volumes. Patients did not want to give up existing physician relationships when their employers changed payment arrangements. ${ }^{134}$ Carriers, therefore, increased their attractiveness to potential purchasers by offering wide networks of caregivers. ${ }^{135}$ Physicians divided their services among the carriers doing business in their communities. ${ }^{136}$ The market ideal of physicians in exclusive competing economic units through which they delivered all or substantially all of their medical services was replaced with a system that Enthoven had described presciently as "the least effective form of competition." 137 With the benefit of hindsight, it is apparent that more than a change in economic incentives would be required for physicians to accept, and develop the skills to carry out, the expanded role delivery system reformers envisioned for them.

\section{B. The Failure of Conditions Precedent}

Market-based reform would require that informed consumers be provided choices among market participants offering diverse delivery and finance options. These conditions did not exist at the beginning of the managed care movement, and to a significant degree they have failed to materialize nearly three decades later, hindering efforts at market-based reform.

Although the employer-based insurance system predated the managed care movement by more than thirty years, when employers' and employees' pur-

133. See generally John D. Blum, The Evolution of Physician Credentialing into Managed Care Contracting, 22 AM. J.L. \& MED. 173 (1996).

134. If employers had offered a greater choice of payers, employees would have had an increased opportunity to maintain their existing medical relationships. Predictably, however, payers offered employers incentives not to offer the option to choose among multiple payers.

135. Some plans selected physicians on the basis of their willingness to accept the proposed fee arrangement and comply with carrier directives. For some, a record of medical malpractice claims or consumer complaints, rather than affirmative evaluations of medical outcomes, was the quality-control mechanism of choice.

136. See Gold, supra note 132, at 15 (reporting that half of physicians participate in five or more plans and one-fourth participate in ten or more plans).

137. Enthoven, Theory and Practice, supra note 22, at 70 (describing the least effective system as one with ten carriers, in which all physicians in solo practice do one-tenth of their practice with each carrier). 
chasing preferences differ, it is an imperfect substitute for consumer choice. ${ }^{138}$ Some proponents of market-based reform recommended the decoupling of employment and health care coverage, while others recommended that employers be required to make available a range of choices among alternative delivery systems and traditional insurers. Neither suggestion was translated into reality: Employers continued to select the option or options that would be offered to their employees, and in many cases they did not provide a wide range of choices.

Consumers continued to have insufficient information upon which to base their choices. To enable consumers to make an informed choice among managed care organizations or between managed care models and conventional forms of health care coverage, information should be detailed enough for a consumer to understand the tradeoffs between managed care organizations and traditional insurance and to make meaningful comparisons among managed care organizations. ${ }^{139}$ Government efforts to encourage the development of health maintenance organizations included some information mandates, requiring HMOs to disclose covered benefits and exclusions, procedures that must be followed to access care, grievance procedures, and the identity of participating providers. ${ }^{140}$ Although this information was necessary to consumers' understanding of their health care coverage, it was insufficient to enable them to assess accurately the medical outcomes afforded by competing plans in comparison with the price charged to enroll in each. ${ }^{141}$ Because competition among plans to secure the business of employer-purchasers centered primarily on cost of coverage rather than on quality of health care, there was little incentive to develop the means to measure, and therefore to manage, health care results. In the absence of comprehensive information about the relative quality and cost of care, as well as the methods used to control cost by limiting use of health care services, reliance on consumer choice to reflect actual consumer preferences was misplaced.

138. For a discussion of how and why employers' and employees' interests might diverge, see Erica Worth Harris, The Regulation of Managed Care: Conquering Individualism and Cynicism in America, 6 VA. J. SOC. POL'Y \& L. 315, 363-64 (discussing agency problems).

139. In a study published in 1998 by the General Accounting Office (GAO), the GAO concluded that consumers were not routinely provided with information about the business practices, financial arrangements, or service performance of the managed care organizations from which they received health care benefits. HEALTH, EDUCATION, AND HumAn SERVICES Division, U.S. GENERAL ACCOUNTING OFFICE, ReP. No. HEHS-98-137, CONSUMER HEAlth CARE INFORMATION: MANY QUALITY COMMISSION Disclosure REQUIREMENTS ARE NOT CURRENT PRACTICE (Report to Congressional Requesters) 3-4 (1998).

140. 42 C.F.R. $§ 417.124$ (b) (2001).

141. Health care quality is difficult to define and more difficult to measure. Ideal comparisons would examine actual health care outcomes achieved in comparison with the health care outcomes that were possible with medical intervention for the measured population. Not all diseases can be prevented or cured, and not all symptoms can be alleviated. Meaningful data would reflect those preventable conditions that were prevented, those curable conditions that were cured, and those incurable that were cared for and made comfortable. See Walter McClure, Health Care Reform Under the 'Buy Right' Strategy, Med. GRoup MGMT. J., Mar.-Apr. 1992, at 16, 23, 76-78 (1993) (discussing the redefinition of the "health care product" as "health results") [hereinafter McClure, Buy Right]. 
Finally, proponents of market-based reform acknowledged that consumers must have a personal financial stake, bearing the brunt of a costly choice while reaping the reward of economical ones, to make cost-conscious coverage and care decisions. The HMO Act mandate envisioned equal employer contributions to traditional coverage options and newly offered health maintenance organizations. But fixed dollar subsidies did not become customary practice. At least for a time, many employers who made health coverage available to their employees continued to pay 80 to $100 \%$ of the premium. ${ }^{142}$ There is evidence, however, that this practice is changing. In 1996, employees paid about $30 \%$ of the premium for family coverage and $22 \%$ for single coverage. ${ }^{143}$ Between 1985 and 1995, the percentage of employees who received single coverage at no cost to them dropped from $64 \%$ to $33 \% .{ }^{144}$

Impediments remain, however, to consumers' having a true economic stake in their choices. When employers shifted from more to less costly coverage options, they typically retained the savings, rather than sharing them with employees who selected less costly alternatives. ${ }^{145}$ Moreover, Congress has failed to reform the tax laws, with the result that employees' preferences for coverage remain skewed by their ability to purchase health care through their employers' health benefit plans with pre-tax dollars. In the end, consumers were left without a financial stake in their decision. Without the potential for personal savings, consumers had little incentive to support health care spending controls. ${ }^{146}$

\section{The Insurance Industry Takeover of Managed Care Reform}

Managed care did not become a major force in health care delivery and financing for more than a decade after the enactment of the HMO Act, when employers rebelled-seemingly en masse-against the ever-increasing cost of their health benefit plans. For a time thereafter, HMOs enjoyed steady increases in enrollment as employers moved away from traditional indemnity coverage. ${ }^{147}$ As market demand for HMOs increased, large commercial insurers saw the emerging trend and assumed center stage in market-based reform.

The traditional customer base of large commercial insurers was equally large commercial enterprises. National employers demanded that the commer-

142. Gold, supra note 132 , at 7.

143. Larry Levitt \& Janet Lundy, Kaiser Family Found., Trends and Indicators in the Changing Health Care Marketplace 35 (1998), at http://www.kff.org/content/archive/1429/trends.pdf (last visited Apr. 4, 2002).

144. Id. at 35 .

145. See Enthoven et al., Consumer Choice, supra note 23, at 3 (noting that individual consumers did not share in the financial savings realized by their employers from health maintenance organizations).

146. See McClure, Medical Care System, supra note 16, at 51-54 (criticizing a national health insurance system funded by the government on the ground that consumers will not support cost control without a personal economic stake).

147. InTERSTUdy PUBlicAtions, HMO TREND REPORT 4, at http://interstudy publications.com/pdf/trendpr.pdf (last visited Apr. 9, 2002). 
cial insurers develop plans in all the employers' locations. Eager to respond to their long-standing customers, commercial insurers developed HMOs in areas not suitable for profitable operation. Insurers frequently did not seek federal qualification for these HMO subsidiaries, giving them more flexibility in benefit design. Employers also encouraged commercial insurers to develop extensive provider networks to avoid disrupting employees' long-standing physician relationships. The pressure to offer large provider panels was enhanced when an insurer's products were the sole option available to a customer's employees.

Anxious for product differentiation and a label that could be applied to a range of benefit designs, commercial insurers adopted the generic term "managed care" to describe health benefit products that attempted to control the cost of care by restricting choice of provider or use of medical services. As a result, various managed care models, which were quite different from the early HMOs, proliferated. With large panels of providers and flexible benefits packages, insurers transformed the world of employee health benefits and brought managed care to larger and larger portions of the American workforce.

Entrepreneurial companies entered the managed care business, taking advantage of opportunities to offer their products to local employers that were less committed to the large commercial carriers. Many of these new market entrants responded to market demand more quickly than old-line commercial insurers. They had strong marketing expertise and were able to accumulate large amounts of capital through public stock offerings. For the first time, HMOs and other managed care organizations became wealth-generating businesses.

With the credibility of the insurance industry solidly behind the managed care revolution, employers began to rethink their employee health benefits strategies. Faced with rapidly escalating health insurance costs, major employers began to replace their traditional indemnity coverage with the managed care plans now offered by commercial carriers and to require all employees to enroll. ${ }^{148}$ To avoid expensive and burdensome state regulation and to take advantage of experience rating, many companies also decided to self-insure, contracting with carriers to administer their plans.

As employers and commercial carriers transformed the landscape of employee benefits, they also transformed the managed care industry. Point-ofservice plans, viewed as the ultimate compromise between indemnity insurance and restricted forms of coverage, slowed the growth of traditional HMOs. With point-of-service options, employees had the option to use network providers in exchange for broad benefits and low out-of-pocket costs or use providers outside the network for fewer benefits and higher out-of-pocket costs. Since pointof-service plans offered many of the cost containment benefits of a tightly managed network and the freedom of choice that many employees coveted, they were very appealing to employers. Insurers marketed point-of-service plans

148. See Levitt \& Lundy, supra note 143, at 24-34. 
with the objective of replacing competing HMOs and regaining their position as the sole carriers for large employer customers.

Responding to a growing managed care marketplace required huge capital expenditures. To offset large start-up costs, insurers had to generate managed care enrollment quickly and produce profits comparable to those earned from their traditional insurance products. Some insurance companies and Blue Cross/Blue Shield plans found it difficult to meet demanding market requirements and remain profitable. During the 1980s and 1990s, insurer-sponsored HMO losses were substantial. ${ }^{149}$ Companies such as Metropolitan Life and Travelers were unable to compete profitably in the intricate world of managed care and abandoned the health insurance business. ${ }^{150}$

During the 1990s, managed care plans responded to new health care dynamics driven in large part by the introduction of Wall Street into the health care market reform. To gain market share, many plans engaged in aggressive pricing, which was unsustainable over the long term. ${ }^{151}$ Smaller plans merged or were purchased by larger plans to achieve fast membership growth, in search of economies of scale, and to gain the advantage needed to negotiate favorable contracts with providers. ${ }^{152}$ The consolidation trend left a small number of large competitors in each community and reduced consumers' options. To satisfy the market's demand for broad provider access, plans contracted with the majority of physicians and hospitals, essentially eliminating competition among providers. Most plans became seemingly undifferentiated commodities.

While profit margins and growth in the early 1990s were high enough to interest Wall Street investors, profits were eroded by the financial burdens associated with fast growth, regulatory requirements, rapid expansion and consolidation, increased health care costs, and managing large physician networks. From 1995 to 1999 , the most profitable plans had margins just above breakeven, while many plans generated losses in the range of $3 \%$ to $13 \%$ of total revenue. ${ }^{153}$ Compounding the problem was the decline in enrollment growth rates. From 1998 to 2000, national HMO growth dropped from $14 \%$ to $0.5 \% .{ }^{154}$ Not surprisingly, the stock prices of many of the publicly held plans dropped sharply, and some of Wall Street's most vocal managed care supporters began to voice concern about the future of the industry.

The managed care revolution required the business expertise of the insurance industry, health care entrepreneurs, and funding from the capital markets to shape the industry to marketplace needs. In the interests of rapid start-up,

149. See Ian Morrison, Health Care in the New Millennium: Vision, Values, and LEADERSHIP 19 (2000); Howard Veit, Managed Care: Still the Best Alternative for Employers, HuM. RESOURCES PROF., Mar.-Apr. 1989.

150. MORRISON, supra note 149, at 20.

151. See Allan Baumgarten, Trend Note: HMO Enrollment, Part 2: Focus on Commercial Plans, at http://www.allanbaumgarten.com/cfusion/view_news.cfm?id=35 (last visited Feb. 26, 2002).

152. MORRISON, supra note 149, at 20.

153. InterStudy Competitive Edge, HMO Industry Report 10.2 (2000).

154. InterStudy Competitive Edge, Regional Market Analysis 10.2 (2000). 
adapting to the market, and achieving enrollment growth, new market entrants did not adopt the founding principles of the prepaid group practice plans. Although prepaid group practice plans continued to exist, they lost market share to commercial carriers selling or administering a range of health benefit products, creating the now-familiar alphabet soup of HMOs, PPOs (preferred provider organizations), POS (point-of-service plans), and EPOs (exclusive provider options) among others. The managed care industry had established its future separate from the goals of the early HMO pioneers and the visions of Paul Ellwood and other delivery system reform advocates.

\section{The Fate of a Dual Mission: Cost Control and Quality Improvement}

The managed care industry promised to control health care spending while improving patient outcomes and consumer satisfaction. ${ }^{155}$ At the height of its popularity with employers, the industry was criticized for interfering with physicians' clinical decisions and not managing the quality of care. As the media began to report stories of alleged managed care abuses, surveys reflected a public backlash against managed care: One survey reported that $58 \%$ of Americans thought managed care hurt quality. ${ }^{156}$ While no credible evidence indicated that quality of health care outcomes had deteriorated under managed care, or that the managed care system delivered poorer quality care overall than the feefor-service system ${ }^{157}$ the managed care industry was losing the confidence of the public and even of some of its advocates. ${ }^{158}$

In an environment of managed care bashing, it was easy to overlook the industry's achievements. The managed care industry did slow health care spending. Thirty years of data showed that managed care plans brought hospital costs under control by eliminating unnecessary hospital stays and by limiting hospital lengths of stay. ${ }^{159}$ Moreover, by extending coverage to services provided in an outpatient setting, it reversed the artificial preference for in-patient care that was created by indemnity insurance benefit designs. By focusing on clinical variability in physician practices, the shift to managed care forced the elimination of some unnecessary care. ${ }^{160}$ It also provided a stabilizing force to professional fees and institutional charges. There is also some evidence that

155. See, e.g., Enthoven, Fortune 500, supra note 71, at 37 (The "goal remains a reformed health care delivery system ... responding to powerful incentives to innovate in order to improve outcomes, patient satisfaction and value for money.")(emphasis in original).

156. MORRISON, supra note 149 , at 76 .

157. See Joseph Gottfried \& Frank A. Sloan, The Quality of Managed Care: Evidence from the Medical Literature, 65 LAW \& CONTEMP. PROBS. 103 (Autumn 2002).

158. Lisa Belkin, But What About Quality?, N.Y. Times, Dec. 8, 1996, §6 (Magazine), at 68 (Paul Ellwood expressed his disappointment that employers seemed much more interested in cost containment than in improved health care quality.).

159. See Congressional Budget Office, The Effects of Managed Care and Managed Competition 2 (1995) (HMO enrollees have lower hospital admission rates and fewer inpatient days than patients enrolled in indemnity plans.).

160. See Uwe E. Reinhardt, The Predictable Managed Care Kvetch on the Rocky Road from Adolescence to Adulthood, 24 J. HEALth POL. POL'Y \& L. 897, 903-05 (1999). 
managed care systems enhanced physicians' cost-consciousness across their practices. For more than a decade, the escalation in health care spending slowed substantially, and for a five-year period from 1993 to 1998 it appeared almost to stop. ${ }^{161}$ The gains, however, are proving temporary. During the year 2000, employers across the country experienced double-digit premium increases as a result of higher-than-budgeted health care spending. ${ }^{162}$ They began that escalation, however, with the enduring benefit of the temporary slowdown achieved by the managed care industry.

From a quality perspective, managed care created an entry point for its enrollees into a complex array of clinical services. Although the concept of physician-as-gatekeeper came to invoke negative images of physician-as-obstacle, when the system was at its best, the designation of a primary care physician ensured that managed care enrollees would have access to and a relationship with a health care professional to track and coordinate their medical needs. ${ }^{163}$ If the shift to managed care did not lead to the creation of an entirely integrated delivery system, an individual patient-physician relationship served to mediate some of the adverse effects of the still-fragmented system. Although comprehensive data on the effects of managed care on medical practice are scarce, it is likely that the restrictions of the managed care industry led to substantive improvements in clinical care that extended beyond managed care enrollees. The managed care industry demanded that physicians provide objective evidence of clinical benefit from medical intervention, thereby eliminating the conventional insurer's deference to clinical practices that may have been little more than "professional habit." ${ }^{164}$ In the process, managed care plans encouraged and facilitated evidence-based medicine through their accumulation of population-based outcomes data. Health care quality can be improved when information about best medical practices is identified and disseminated throughout the professional community. ${ }^{165}$ During the 1990 s, several voluntary organizations proposed mechanisms and measures to assess the quality of health plans, ${ }^{166}$ but they did not agree on a standard set of quality measures. As a result, the managed care industry confronted a costly burden to respond to

161. Clark C. Havighurst, The Backlash Against Managed Health Care: Hard Politics Makes Bad Policy, 34 IND. L. REV. 395, 396, 396 n.4 (2001) [hereinafter Havighurst, Backlash]; Clark C. Havighurst, Is the Health Care Revolution Finished?-A Forward, 65 LAW \& CONTEMP. PROBS. 1 (Autumn 2002).

162. See Kaiser Family Found. \& Health Research \& Educ. Trust, Employer Health Benefits Annual Survey 2 (2001) (premiums increased by an average of eleven percent in 2001), at http://www.kff. org/content/20010906a/HRETChartpack.pdf (last visited Apr. 5, 2002). The annual 2001 Towers Perrin Health Care Cost Survey also found that the cost of large employers' health benefit plans increased about thirteen percent on average in 2001, the highest year-over-year percentage increase in more than a decade. Towers Perrin, 2001 Health Cost Survey 3, 5 (2001).

163. See Havighurst, Backlash, supra note 161, at 397 (noting improved accessibility and continuity of care).

164. See William M. Sage, Physicians as Advocates, 35 Hous. L. REV. 1529, 1578-79 (1999).

165. Id. at 1577 .

166. These included the National Committee for Quality Assurance, the Joint Commission on the Accreditation of Healthcare Organizations, and some employer coalitions and quality consultants. 
myriad diverse, sometimes duplicative, efforts to measure and monitor quality. ${ }^{167}$

Market-based reform proved an imperfect mechanism for quality improvement. The marketplace provided only disincentives to excel in caring for the very sick. An organization that managed the care of seriously or chronically ill patients exceptionally well risked attracting more than its actuarially predicted share of costly cases. ${ }^{168}$ This marketplace disincentive to develop skills at providing high-quality, cost-effective care in complex cases created suspicion among vulnerable patients. An opportunity to improve quality and control health care spending on the costliest cases was lost.

Some comprehensive quality initiatives fell victim to a market that emphasized cost-based competition. ${ }^{169}$ Unlike the prepaid group practice plans on which the managed care revolution was founded, many newly created plans that resulted from the insurer takeover of the managed care industry lacked the infrastructure to initiate quality improvement programs and intervene in the quality of care delivered by their widely dispersed independent providers. ${ }^{170}$ Employers did not perceive quality as a critical issue and showed little inclination to direct employees to plans with the infrastructure to manage quality of care. In the absence of purchaser demand, competition on the basis of quality failed to materialize.

\section{VIII}

\section{SUGGESTIONS FOR FUTURE DIRECTIONS}

Too often discussions of health care reform resort to utopian or simplistic solutions. Certainly, the nation's health care system has not achieved medical nirvana, nor is it likely to do so. Both returning to a mythical past and staying the current course, however, are untenable. The complexity of medical science and technology outpaced the technical abilities and financial means of kindly

167. MORRISON, supra note 149 , at 57-62.

168. In contrast, physicians in a fee-for-service system were rewarded for their superior efforts. And, even when those incentives are moderated by managed care organizations, physicians continue to reap the psychic rewards and professional prestige for clinical management of complex cases. In the absence of personal financial disincentives, such non-financial rewards may be sufficient. This reward system is to be encouraged, because it is desirable that the sickest people are directed to the caregivers with the most skill in caring for them.

169. MORRISON, supra note 149 , at 79.

170. Howard Veit, co-author of this article, served as a consultant to many prepaid group practice plans during this period. Many of these plans had well-publicized quality improvement programs and had initiated disease management programs to improve health care outcomes for several specific conditions. Veit observed, however, that, in light of the market conditions and the resulting loss of market share, the group practice plans had to make critical and gut-wrenching decisions. Should they risk fighting against market pressures and remain a limited network, quality oriented plan? Alternatively, should they direct limited resources to enlarging their provider networks, often into new geographic areas? Survival often meant opting to increase their networks. Management teams all over the country made a clear choice to satisfy the market with plenty of access, knowing that this choice might force them to de-emphasize their priority on quality management. Many of these plans still struggle to allocate sufficient resources to keep quality management programs alive, while others have significantly reduced or eliminated these programs. 
country doctors long ago. Cost has always mattered: An earlier era merely offered fewer sellers and fewer services for purchase. The level of health care spending that would result from a present-day cost-unconscious health care delivery system would soon outstrip society's ability to fund health care, until eventually only the most profitable enterprises and the wealthiest citizens would be able to afford health care coverage or medical services. The concept of managed care was based on a planned shift of ultimate power to individual consumers who were to have the choice and the information about cost and quality to make wise, economical selections. Armed with the tools of the marketplace and freed from the perverse incentives of indemnity insurance and feefor-service medicine, consumers and caregivers were going to reshape health care delivery and financing. But the conditions precedent failed, the stakeholders did not behave as predicted, and the result is not to anyone's liking.

As an approach to improving the status quo, both the body politic and the general populace have exhibited a clear preference for evolution over revolution. ${ }^{171}$ There is no evidence of the political will or public commitment to confront fundamental change to a market-based health care delivery and financing system. Nor is there any persuasive evidence that another alternative would be more beneficial. ${ }^{172}$ Evolutionary aims are modest: to right missteps and make moderate changes of course in search of net improvement among admittedly imperfect alternatives. The managed care industry, despite its flaws, has access to substantial capital, organizational capabilities, and technology to enable it to improve services and contribute to efforts to control health care spending. The task for modern day would-be reformers is to design and propose targeted interventions to address imperfections in the current system. We offer here a few modest suggestions.

\section{A. Patient Self-Help}

Renewed calls for health care reform come at a time when unprecedented amounts of medical information are available to consumers. In this environment, patient self-help could yield modest cost reductions. In the colonial period and throughout the time that predated widespread health care insurance, health care was provided primarily through self-help and family assistance, with the information offered by newspapers and almanacs. ${ }^{173}$ That practice diminished as access to professional care, scientific knowledge, and medical technology expanded. Today, the Internet and the medical information that it has made available have led to a renaissance of colonial-age beliefs that ordinary

171. The rejection of overhaul proposals, from the 1970s plans of Senator Edward Kennedy to the 1990s proposal of President Clinton, provide persuasive evidence for this assertion.

172. See David A. Hyman \& Mark Hall, Two Cheers for Employment-Based Health Insurance, 2 YAle J. HeAlth POL'Y L. \& ETHICS 23, 24 (2001) (noting that one of the shortcomings of the managed care backlash has been the failure of most commentators to appreciate the benefits of existing arrangements and the trade-offs associated with the preferred alternatives).

173. STARR, supra note 6 , at 32 . 
people are competent to treat many minor illnesses without physician or other specialty intervention. ${ }^{174}$ In 1980, Alain Enthoven cited a study by the National Center for Health Statistics in which physicians reported that $48.5 \%$ of all patient office visits were for problems that were not serious and did not require expert intervention. ${ }^{175}$ Although physician charges account for only a relatively small percentage of total health care expenditures, ${ }^{176}$ informed self-help for minor ailments offers an opportunity for savings. ${ }^{177}$ In addition, individuals who have the capacity to educate themselves about their medical needs and use the information and tools available to them will be better partners to cost-conscious physicians when they require medical intervention.

\section{B. Facilitating Quality-Based Competition}

If individuals are to take a more active role in managing their own health, they must have better information with which to judge the comparative quality of care. The current managed care marketplace measures the cost of coverage without a reliable comparison to the quality of care delivered in exchange. If managed care organizations and caregivers are going to compete based on quality as well as cost, they must first measure quality using reliable information about medical outcomes. ${ }^{178}$

Walter McClure has made a persuasive case for adopting his "buy right" strategy in which purchasers would base their spending decisions on the best available information about medical outcomes and competitive pressures would induce caregivers to produce reliable data. ${ }^{179}$ Some employers have formed "The Leapfrog Group" to use their purchasing power to motivate health plans and providers to reduce the incidence of medical errors, basing their purchasing decisions on medical outcome evidence. ${ }^{180}$ To date, however, most purchasers have seemed content to make their decisions on the basis of cost, coupled with the absence of any evidence of poor quality outcomes. The principal private accrediting agency for managed care plans, the National Committee on Quality Assurance, has focused on inputs and process measures, rather than medical outcomes, and has conceded that it does not measure the quality of care actu-

174. See Leah Beth Ward, Web Plays a Huge Role as Health Advisor, DALlas MoRning NEWs, Nov. 27, 2000, at 1D (reporting that fifty-five percent of Americans with Internet access use the Web to retrieve health or medical information).

175. ENTHOVEN, HEALTH Plan, supra note 20, at 31.

176. Id. at 31-32 (reporting that physicians' charges accounted for eighteen percent of the total at the time of the study).

177. See Anne R. Somers, Health Care in Transition: Directions For the Future 79-85 (1971) (indicating a need for consumer health education).

178. See, e.g., Paul M. Ellwood, Outcomes Management: A Technology of Patient Experience, 99th Shattuck Lecture to the Annual Meeting of the Massachusetts Medical Society (May 21, 1988), in 318 NEW ENG. J. MED. 1549, 1550 (1988) (describing information as the "central nervous system" of modern medicine).

179. McClure, Buy Right, supra note 141.

180. See Hyman \& Hall, supra note 172, at 34-35 (also discussing the Pacific Business Group on Health). 
ally provided to enrollees of the plans it reviews. ${ }^{181}$ In the absence of purchaser demand, health plans do not compete on the basis of the quality of outcomes, over which they have little direct control. In the absence of demand, medical professionals have little impetus to produce the kind of medical outcome data that would subject providers to uncomfortable public scrutiny. The system seems to have settled into a socially undesirable stasis.

There is much truth in the adage that medicine follows Medicare. The federal and state governments should become active participants in McClure's buyright strategy, basing their purchasing decisions on data about the quality of medical interventions and the incidence of medical error. ${ }^{182}$ This strategy could be applied to individual and institutional caregivers through selective contracting, as well as to managed care plans that wish to offer their products to government beneficiaries.

Producing severity-adjusted medical outcomes data, however, will be a complex and costly undertaking. The federal government can use its awards of research grants and federal funding to facilitate the development of medical outcomes measures as it creates a demand for that information through its purchasing decisions. If usable methods to measure medical outcomes were more widely available, private purchasers would likely follow the government lead in using data to make purchasing decisions and providing them to employees for their individual choices.

The ultimate goal should be a national medical database for a broad range of medical conditions to which all market participants have access. The government should require managed care organizations, payers, and providers to produce information that would build this national database. Although some data exist, there is no centralized effort to standardize or stimulate data collection and storage. Moreover, no systematic efforts have been made to update available data to reflect new information and new technologies. It is unlikely that market competitors will engage in the kind of collaborative endeavor that would be required to undertake a task of this magnitude. National leadership and federal expenditures are essential.

\section{Empowering Consumer Choice}

Health plans must compete for the business of individual consumers in the context of the existing group-based system. Despite the shortcomings of the employer-based insurance system, a group-purchasing model offers information and marketplace advantages for individual consumers. ${ }^{183}$ Health care coverage

181. See Margaret E. O'Kane, NCQA: Using Market Pressure to Promote Quality in Managed Care, in The Challenge of Regulating Managed Care 142, 146 (John E. Billi \& Gail B. Agrawal eds., 2001) (noting that NCQA's accreditation strategy is to evaluate systems and processes).

182. A shift from claims-payer to value purchaser of medical services will likely require changes in federal and state law. It will also require political will. See Robert A. Berenson \& Dean M. Harris, Using Managed Care Tools in Traditional Medicare: Should We? Could We?, 65 LAW \& CONTEMP. PROBS. 140 (Autumn 2002).

183. For a comparative institutional analysis of an employment-based insurance system, see Hyman 
is complex. Use of an agent to gather information about plan options, evaluate coverage and cost, and present information to individual consumers is more efficient than placing that burden on each individual. If quality information became available, group purchasers would be more likely than individual consumers to use the data to make purchasing decisions. ${ }^{184}$ Group purchasing also enhances the market power of the consumer in bargaining with the carrier. One need only examine the market for individual coverage to discover use of competitive strategies that could drive the nation ever further from universal coverage: risk selection to deny coverage to those who are most likely to require care and discontinuance of coverage when risks materialize. ${ }^{185}$ The creation of private purchasing associations to assume the functions currently performed by employers would take time, increase costs, and likely involve different shortcomings. Many of the imperfect agency problems with an employer-based model can be alleviated by modest changes to the current system. While such modifications might be difficult, they are more easily achievable than wholesale change to the way health benefits are delivered to the working population.

Purchasers should increase the number and types of choices that they make available to their employees or other group members. ${ }^{186}$ Failure to do so will ensure a system in which carriers are responsive to purchasers rather than to patients. Many purchasers have so far proved themselves disinclined to take these steps voluntarily, and individual carriers have many incentives to discourage them from doing so. ${ }^{187}$ Lawmakers might revisit the market-mandate as a means to bolster competition if employers failed to offer voluntarily a designated number of different benefit designs to their employees. A reinstituted and revised statutory mandate, similar to the one used in the federal HMO Act, could be made available to conventional insurers as well as to a full range of alternative financing and delivery models to facilitate competition at the individual consumer level by requiring groups to offer a wide range of options. To minimize disruption to the annual enrollment period, options could be closed after an employer offers a single open access model, including indemnity or pre-

\& Hall, supra note 172 .

184. See Kaiser Family Found., National Survey on Americans as Health Care Consumers: An Update on the Role of Quality Information 4 (2000) (finding that people report reliance on recommendations of friends and family rather than on standardized quality indicators; only one in ten report using quality information), available at http://www.kff.org/content/2000/3093/AHRQToplines.pdf (last visited Apr. 3, 2002). The survey's results are predictable due to the complexity of analyzing such data and the emotion-laden tradeoffs that are involved in choices about medical care. See Russell Korobkin, The Efficiency of Managed Care

"Patient Protection" Laws: Incomplete Contracts, Bounded Rationality, and Market Failure, 85 CORNELl L. REV. 1, 51-55 (1999).

185. See Alain C. Enthoven, Managed Competition in Health Care and the Unfinished Agenda, in Health Care FinAnCing Rev., 1986 Ann. Supplement, at 105, 107-110 (discussing competitive strategies in the individual coverage market).

186. See Enthoven et al., Backlash, supra note 23, at 7-8.

187. In 1997, fifty-three percent of employees in large firms and twenty percent in small firms were offered a choice among plans, and this choice did not necessarily include different types of plans. See Gold, supra note 132, at 9. 
ferred provider organization plans, two health maintenance organizations or other closed panel plans, and a safety valve plan, like the current point-of-service options that permit patients to seek care outside the network of contracted providers at increased cost.

An expanded choice of plans at the group level might also decrease the pressure on health plans to create ever wider networks of providers and increase the competition among health plans with different network configurations. Differential premium structures between plans with larger panels and those with more manageable small closed panels would lead to consumer choice based on price, if consumers are permitted to retain the savings. Smaller networks should also increase competition among caregivers to participate in alternative delivery and financing plans. And if a trend toward smaller networks is coupled with greater quality-based competition, more progress might be made toward the creation of truly integrated clinical care.

Even a multiplicity of choices will not produce informed competition at the level of individual consumers without meaningful information about those choices. Consumers should be informed about the techniques, organizational forms, and incentives that characterize each of their options, as well as about the cost of coverage and quality of care provided by each managed care plan. ${ }^{188}$ Private accreditation agencies could be used to create standards for, and to oversee information disclosure by, managed care plans. Proposed federal patient protection legislation would require more complete disclosure of plan rules than is now customary. ${ }^{189}$ If federal law is amended to permit a wider array of judicial challenges to health plan practices, full disclosure in a format reasonably intended to inform consumers should provide a defense to any cause of action based on truth in advertising or consumer protection statutes.

Market and information mandates offer improvements, but not universal solutions. Self-insured plans typically rely on a single benefit design managed by a third party administrator with specified limits on discretionary use of plan assets. Information about a single option provides little more than an alert to consumers to take precautions to protect their own interests, although even this information might be useful. When an employer plan does not offer any insured product designs, the proposed mandate will not foster competition, at least not in the short term. It is possible that, as alternative delivery and financing systems offer greater benefits in quality and cost than a self-insured employer could achieve operating its own plan, employers may again elect to focus on their core businesses, insure health care risks, and allow others to manage them. Similarly, a mandate fosters competition only if payers elect to

188. Jacob S. Hacker \& Theodore R. Marmor, The Misleading Language of Managed Care, $24 \mathrm{~J}$. HEALTH POL. POL'Y \& L. 1033, 1038-1042 (1999) (arguing that payers should not rely on "slogans" but should be required to provide meaningful information in accurate terms).

189. See Bipartisan Patient Protection Act, S. 1052 and H.R. 2563, 107th Cong. $\$ 121$ (2001). The President also supports federal disclosure provisions. See Letter from the President to the Speaker of the House of Representatives and the Senate Majority Leader, Feb. 7, 2001, at http://www. whitehouse.gov/news/releases/20010207-4.html (last visited Feb. 26, 2002). 
utilize it, but they are unlikely to do so with small groups or groups with unfavorable experience. Over time, purchasing cooperatives might be formed that combine these groups into organizations that are more attractive to payers, and competition for their business will ensue. ${ }^{190}$ To the extent that managed care organizations are prompted to compete on the basis of selection by the individual consumer in some groups, they will be more likely to engage in the same activities across their benefit lines as a means of controlling administrative costs.

\section{Confronting a Role for Physicians}

Physicians have an unavoidable role in controlling health care spending and achieving cost-effective clinical care. ${ }^{191}$ Their decisions have always dictated much of health care spending, and even if consumers assume a larger role in their own health care, reliance on medical judgment is inevitable in the complex cases that account for the majority of health care spending. In addition, physicians are in the best position to assess different patient preferences and functional needs and to educate patients about the incremental gains or risks associated with additional increments of clinical intervention. They are also going to be essential to any broad-based effort to collect medical outcomes data.

In 1970, Ellwood stated:

[I]t is the indispensability of the physician's judgment that makes it unlikely that the price regulation approach can succeed. Only the physician can determine what care is necessary, and therefore, only [s] he can eliminate unneeded expense. The physician cannot be policed to do so, but must be motivated by professional ethics, and by organizational arrangements which align... [the physician's] economic incentives with those of the consumer. ${ }^{192}$

The managed care industry assumed, mistakenly, that a change in physician financial incentives alone could do what direct price regulation could not. As managed care organizations confront adverse publicity and increased liability exposure, they are returning some control over medical decision-making to attending physicians and their patients. The focus is once again on the role of the caregiver in assuring wise use of resources.

History has proved that merely changing reimbursement strategies does not change medical practice. To control health care spending, physicians must have professional, as well as financial, incentives. Cost-increasing behavior was caused not only by economic incentives but also by psychic rewards of satisfying patient demand and the professional prestige associated with highly specialized technological care. ${ }^{193}$ Physicians' mores must change to embrace new roles and to reward cost-effective clinical decision-making. They must have information upon which to base cost-conscious decisions about which treatments are effica-

190. Clinton's defeated health reform plan included an analogous provision.

191. See Victor R. Fuchs, Economics, Values, and Health Care Reform, 86 AM. ECON. REV. 1, 17 (1996) (discussing an economist's view of the role of physicians in health care spending control).

192. Ellwood, The Health MaintenanCe Strategy, supra note 43, at 7.

193. ENTHOVEn, HeAlth Plan, supra note 20, at 16 (financial incentives are reinforced by patient expectation and prestige). 
cious and the costs associated with the range of alternative interventions. Physician education must extend to the realm of public health and epidemiology to teach future physicians to develop skills in predicting the needs of populations. ${ }^{194}$ This evolution of medical practice will not be a simple one, nor is it likely to occur by pronouncement or legal fiat. If continual improvement in cost-effective clinical care is to occur, however, it is an essential one. Unless providers can be persuaded or required to redirect their energy into innovative approaches to manage medical practice, the health system will be left with a medical management vacuum that cannot easily be filled by other stakeholders.

\section{E. Re-examining Comprehensive Coverage and Patient Cost Sharing}

The benefit designs offered to consumers have become static. They tend to be based on comprehensive coverage for all "medically necessary" services with limited cost sharing. There is little differentiation within design categories and a dearth of low-cost options. The indemnity plans against which managed care plans were to compete have largely disappeared from the marketplace. Consumers who would prefer not to shift the risk of routine care or who do not want, or cannot afford, to purchase a comprehensive benefit package of managed services have few meaningful alternatives in the current marketplace. The proposed patients' bill of rights legislation does nothing to remedy this problem and, to the extent that it expands mandatory coverage and thereby further restricts choice, might exacerbate it. ${ }^{195}$

In the period immediately following the establishment of the Medicare and Medicaid programs, society had accepted, in principle, that health care coverage should be universal, comprehensive, and begin with the first dollar of expenditure. ${ }^{196}$ The health maintenance organization concept was built upon a delivery model in which all or a substantial part of health care services would be delivered or coordinated by a closed group of physicians. In that model, consumers were presumed to purchase care rather than coverage. The professional staff would provide the medical management necessary to ensure cost effectiveness, and patient financial incentives to avoid excess utilization were deemed unnecessary. ${ }^{197}$ Instead, many managed care benefit designs are offered by organizations with little capacity to integrate or manage clinical care. Additionally, ERISA ensured that health plans participating in private employer-sponsored

194. The Institute of Medicine identified this problem in 1974. See Institute OF Medicine, supra note 59, at 30 (as a result of medical education's focus on acute episodic care, physicians are poorly trained to conserve resources while providing good quality care to the patient over a period of time).

195. Among the areas of consensus in House and Senate bills passed during the 107th Congress are mandatory access to out-of-network specialists in some circumstances, mandatory coverage for emergency care when a "prudent layperson" would believe such care was required, and continuation of access to a caregiver who leaves the network. See StePHANIE LEwIS, A Guide to THE Federal PATIENTS' BILL OF RIGHTS DEBATE 5 (2001), at http://www.kff.org/content/2001/3179/ DebatePaper.pdf (last visited Feb. 26, 2002).

196. See supra text accompanying notes 27-30.

197. Enthoven, Health Plan, supra note 20, at 33-34 (discussing his views of why coinsurance and deductibles were an ineffective means of cost control). 
health benefit plans would not be held legally accountable for the quality of care provided under their auspices, thereby eliminating an important incentive for active quality management. ${ }^{198}$

In the current managed care environment, consumers are typically purchasing coverage rather than services. Alternatives to the comprehensive coverage packages should be given an opportunity to compete in the marketplace. Just as proponents of health care system reform recommended that consumers have financial incentives to make cost-conscious coverage selections, consumer cost-sharing offers a means to encourage cost-conscious clinical choices as well. The use of copayments and coinsurance would ensure that patients do not view medical care as a free service, thus reducing, albeit modestly, the moral hazard associated with third-party coverage. A sliding scale of copayment amounts and coinsurance percentages could be incorporated into coverage design to reinforce the use of cost-effective clinical options: Patients who accept the least costly alternative would have higher coverage levels than those who opt for more costly options. Patients who share the financial consequences of their choices are more likely both to accept lower-cost care and to be satisfied with their decision. ${ }^{199}$ The knowledge that patients bear some of the costs of their care will restore an element of physician cost-consciousness that was lost when third-party payment gained dominance. And if that fails to have the desired effect, cost-conscious patients are more likely to bargain with their physicians over medical charges.

The resistance to the use of consumer contributions to the cost of their own care is based, at least in part, on a paternalistic notion that the health care financing system can and should protect patients from themselves. Advocates of comprehensive coverage for all argue that consumers who are asked to contribute to the cost of their own care will avoid preventive and routine care, thereby putting themselves at higher risk for serious illnesses which are more costly to treat. The risk of undetected serious illness or occurrence of preventable illness should provide strong personal motivations to seek appropriate medical care. Society will continue to provide the safety net of comprehensive coverage coupled with minimal out-of-pocket expenses to some segments of the population. Until society is prepared to provide for universal coverage, the current system is ill-equipped to protect everyone from his or her own foibles.

Coverage options incorporating cost sharing do not offer a panacea. They

198. The proposed federal patient protection legislation would restore accountability by mandating external review for certain kinds of health plan decisions and providing consumers who are harmed by their health plans a right to sue for damages. Although both the House and Senate bills provide for these remedies, they are the subjects of key differences that, if any legislation is to be enacted, will have to be resolved in committee. See LEWIS, supra note 195, at 5-8. While consumers might regain some lost confidence from the ability to seek redress, this accountability might well have the unintended effect of increasing the number of uninsured Americans and discouraging innovative means to control health care spending. A full discussion of this debate is beyond the scope of this paper. See generally David A. Hyman, Regulating Managed Care: What's Wrong with a Patient Bill of Rights, 73 S. CAL. L. REV. 221 (2000). For a comparison of federal proposals, see LEWIS, supra note 195.

199. Cf. Enthoven et al., Backlash, supra note 23, at 7-8. 
will be inappropriate for some segments of the population in all circumstances, including Medicaid beneficiaries, dual Medicare and Medicaid eligibles, and other low-income groups. States or the federal government might elect to prohibit them in such plans, or the private sector might elect not to offer them or employers not to purchase them. Societal protections or coverage differentials could be devised to protect vulnerable populations. For example, pediatric services could be exempted from patient-pay obligations. Despite Fuchs's argument that physicians should not serve as "part-time amateur welfare administrator[s], ${ }^{200}$ in the absence of public financial assistance to the indigent, caregivers have proved their willingness to waive patient-pay amounts when they are permitted to do so. ${ }^{201}$

The use of patient-pay methods are also ill-suited for patients during episodes of serious illnesses, when clinical options might be fewer and patients would be particularly burdened by acquiring information about the possible consequences of their various options. ${ }^{202}$ The retention of annual maximums for out-of-pocket expenditures should ensure that patient cost-sharing does not continue throughout the course of treatment for serious or chronic illness. Unless we are prepared to require the use of community rating to ensure that the costs of caring for the ill are shared equally among the healthy and the sick, it is unfortunate but inevitable that those who require more health care services will bear at least some of the increased cost of those services.

The most significant challenge to patient cost-sharing will probably come from labor unions and employees accustomed to current practices. Long-held expectations are slow to change. An appreciation that employees pay the cost of coverage through lower wages and other benefits might contribute to a willingness to accept other coverage designs. In the end, this is an issue that will have to be worked out in each workplace. This proposal is intended to facilitate an increase in the number of options available to consumers, not to dictate any consumer's choice among the available options or to suggest that a benefit design that includes elements of cost-sharing would be appropriate for all consumers.

IX

\section{CONCLUSION}

The evolution to a managed care system did not achieve the complete, fundamental change in the health care delivery system that was envisioned by some of its early proponents. As the managed care movement evolved beyond the

200. See Fuchs, Traditional Practice, supra note 1, at 155.

201. Waivers of copayments or coinsurance sometimes constitute insurance fraud under state law or an unlawful inducement under the Medicare and Medicaid Patient and Program Protection Act.

202. Some data suggest that patients are ill-equipped to make rational decisions when they are seriously ill, making cost sharing particularly inappropriate. Eric J. Cassell et al., Preliminary Evidence of Impaired Thinking in Sick Patients, 134 ANNALS INTERNAL MED. 1120, 1122 (2001) (judgment of sick hospitalized patients approximates that of children younger than ten years old). 
prepaid group practice model, it focused primarily on methods used to spread the cost of health care services. Discounting fees and withholding payments as a means to eliminate useless, duplicative, or wasteful health care services generated temporary savings, but those methods alone did not lead to sustained costeffective clinical practices. The system continues to lack the information and incentives necessary to cause consumers, patients, and physicians to make costconscious clinical choices or to require payers to offer a wide range of benefit options. As the health-care industry evolves, the challenges to increase information, options, and choice in a competitive marketplace remain to be resolved. 